\title{
Efeito antimicrobiano de plantas medicinais: uma revisão de estudos científicos
}

\begin{abstract}
A utilização de plantas medicinais no tratamento de doenças retoma à antiguidade. Vários estudos científicos demonstram os efeitos, tanto positivos, quanto negativos da utilização de plantas medicinais. Este trabalho teve como objetivo realizar uma revisão da literatura para identificar o efeito antimicrobiano de 12 plantas medicinais constantes nas listas do RENISUS e RENAME. Para tanto, realizou-se a pesquisa no Portal de Periódicos da CAPES, utilizando o nome científico da planta e o termo 'antimicrobial'. Foram incluídos artigos completos que demonstrem o efeito antimicrobiano das plantas medicinais estudadas. Como resultado foi analisado um total de 97 artigos completos, cujo assunto era diretamente relacionado aos objetivos do estudo, sendo equivalente a 1,23\% do total encontrado. Com isso, foi possível visualizar que as espécies Schinus terebinthifolia (aroeira-vermelha), Glycine max (soja) e Mentha x piperita (hortelã) são as com maior número de publicações com a comprovação do efeito medicinal, sugerindo o sucesso de seu uso em estudos. Em todas as espécies o efeito medicinal é comprovado visto que estas estão citadas nas listas oficiais de uso no Sistema Único de Saúde (SUS), porém, Cynara scolymus, Harpagophytum procumbens, Maytenus ilicifolia e Rhamnus purshiana não foram constadas nos artigos selecionados, demonstrando a necessidade por atualizações científicas a respeito de sua atividade antimicrobiana, uma vez que em artigos excluídos, foram citados. Foi constatado, também, que, embora foram utilizadas diversas partes das plantas, o predomínio foi do uso das folhas.
\end{abstract}

Palavras-chave: Antibacteriano; Antifúngico; Produtos Naturais; Saúde.

\section{Antimicrobial effect of medicinal plants: a review of scientific studies}

The use of medicinal plants in the treatment of diseases goes back to antiquity. Several scientific studies demonstrate the positive and negative effects of using medicinal plants. This study aimed to conduct a literature review to identify the antimicrobial effect of 12 medicinal plants on the RENISUS and RENAME lists. To this end, the research was carried out in the CAPES Journal Portal, using the scientific name of the plant and the term 'antimicrobial'. Complete articles that demonstrate the antimicrobial effect of the medicinal plants studied were included. As a result, a total of 97 complete articles were analyzed, whose subject was directly related to the study objectives, being equivalent to $1.23 \%$ of the total found. With this, it was possible to see that the species Schinus terebinthifolia (red pepper), Glycine max (soybean) and Mentha x piperita (mint) are the ones with the largest number of publications with proven medicinal effect, suggesting the success of its use in studies. In all species the medicinal effect is proven, as they are cited in the official lists of use in the Unified Health System (SUS), however, Cynara scolymus, Harpagophytum procumbens, Maytenus ilicifolia and Rhamnus purshiana were not included in the selected articles, demonstrating the need for scientific updates regarding its antimicrobial activity, since in excluded articles, were cited. It was also found that although several parts of the plants were used, the predominance was the use of leaves.

Keywords: Anti-bacterial; Antifungal; Natural products; Cheers.

Topic: Experimentação Agrícola

Reviewed anonymously in the process of blind peer.
Received: 06/06/2019

Approved: 07/07/2019
Claudete Rempel (iD)

Universidade do Vale do Taquari, Brasil http://lattes.cnpq.br/8340497822227462 http://orcid.org/0000-0001-8573-0237 crempel@univates.br

\section{Mônica Jachetti Maciel (iD)}

Universidade do Vale do Taquari, Brasil http://lattes.cnpq.br/2575088289818885 http://orcid.org/0000-0002-6863-2181 monicajm@univates.br

\section{Patrícia Caye Bergmann (it)}

Universidade do Vale do Taquari, Brasil http://lattes.cnpq.br/8497886339173527

http://orcid.org/0000-0003-0081-9158

patricia.bergmann@universo.univates.br

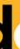

DOI: 10.6008/CBPC2179-6858.2019.004.0006

\author{
Ana Paula de Borba Morás (ID) \\ Universidade do Vale do Taquari, Brasil \\ http://lattes.cnpq.br/5476707840992154 \\ http://orcid.org/0000-0002-1535-8350 \\ ana.moras@universo.univates.br \\ Cinthia Goettens (it) \\ Universidade do Vale do Taquari, Brasil \\ http://lattes.cnpq.br/4473279469231427 \\ http://orcid.org/0000-0001-8261-402X \\ cinthia.goettens@universo.univates.br
}

Referencing this:

REMPEL, C.; MACIEL, M. J.; BERGMANN, P. C.; MORÁS, A. P.; GOETTENS, C.. Efeito antimicrobiano de plantas medicinais: uma revisão de estudos científicos. Revista Ibero-Americana de Ciências Ambientais, v.10, n.4, p.57-82, 2019. DOI:

http://doi.org/10.6008/CBPC2179-6858.2019.004.0006 


\section{INTRODUÇÃO}

Os seres humanos sempre buscaram nos recursos ambientais uma solução para a cura de ferimentos e doenças (MARMITT et al., 2015), as plantas são consideradas as principais opções para tal, sendo empregadas desde tempos remotos, sendo que seu uso deu origem à Medicina Tradicional (ROCHA et al., 2015). As enfermidades mais comuns que acometem a população brasileira decorrem de infecções por microrganismos no ambiente, como bactérias e fungos, e seus tratamentos dependem de compostos inibidores, como os antibióticos, para findar a ação dos patógenos e assegurar a recuperação do indivíduo. O uso desses medicamentos é uma alternativa provida da revolução científica que vem sendo amplamente introduzida nos tratamentos, tendo como uma de suas consequências positivas ao longo dos anos o aumento da expectativa de vida, visto que doenças por microrganismos eram os principais motivos do óbito precoce no passado.

Segundo Pessini et al. (2006), o prolongamento da longevidade está relacionado a alguns aspectos, dentre eles a evolução científica medicinal, ou seja, por meio de novas maneiras de tratar o paciente, tanto por medicamentos ou tecnologias diferenciadas. Porém, o acesso a esta inovação da ciência se torna prejudicado a alguns grupos de pessoas devido à dificuldade de adquirir os medicamentos por motivos financeiros, a sensação do usuário de não estar mais obtendo o efeito desejado, a variedade de efeitos colaterais que podem ser de inexistentes a intensos, dentre outros motivos (SILVA et al., 2015).

Além disso, o uso intensivo de antibióticos acaba por acarretar o aumento da resistência dos microrganismos causadores das doenças, estimulando novos estudos e propiciando o desenvolvimento de antimicrobianos mais eficazes (ANTUNES et al., 2006), gerando maiores custos e demandando muito tempo para a obtenção de um resultado conclusivo e eficaz.

Lessa et al. (2012) obteve o extrato da planta Mikania glomerata, na qual testou seu efeito antimicrobiano contra Streptococcus mutans em dentição humana por meio de enxágue bucal com as soluções, e compararam a ação à da substância química clorexidina, que tem a mesma finalidade; os resultados apontaram que a eficácia do extrato natural é idêntica ao da substância sintética e, ainda, sem proporcionar riscos à saúde dental, como mudança na coloração dos dentes, desconforto bucal e formação de tártaro, complicações essas adquiridas com o uso de clorexidina a longo prazo.

Esta questão mostra que os fitoterápicos são uma boa opção para curar enfermidades, pois além de proporcionar o efeito medicinal são mais acessíveis, eficazes quando respeitadas as doses recomendadas, alguns até mais seguros devido aos efeitos colaterais poderem apresentar menor intensidade e não demandam de valores tão altos, quando comparados com a maioria dos medicamentos sintéticos.

Conforme Maciel et al. (2002), a utilização de plantas medicinais no tratamento de enfermidades é comum em comunidades com índices maiores de pobreza, sendo que muitas vezes esta é a única alternativa àquela população, pois não há estrutura que permita a implantação de tecnologias médicas, bem como o acesso a centros hospitalares também é prejudicado. Veiga-Junior et al. (2005) comenta que, nos países em desenvolvimento, há grande incentivo para a utilização de plantas medicinais, em que os produtores de ervas 
em grande escala prometem vida longeva e saudável aos usuários, tendo como base que essa é uma prática antiga, onde os antepassados vêm sendo curados de suas enfermidades a milênios. A população de idade avançada, geralmente no interior de cidades e que teve maior convívio com a natureza durante sua vida, já carrega determinado conhecimento da ação terapêutica de algumas plantas, optando pelo uso delas como tratamento primário de sintomas pois acreditam que não cause nenhum efeito prejudicial à saúde (ÂNGELO et al., 2014). Essa atitude pode se tornar perigosa, visto que seu uso, sem a validade científica de ação medicinal, pode agravar os sintomas ou provocar outras complicações ao indivíduo.

A busca pela comunidade, principalmente a de baixa renda, a respeito deste assunto está em crescimento (MARMITT et al., 2015), fortalecendo a necessidade de explorar propriedades curativas e preventivas de plantas. Além da capacidade medicinal, é importante o estudo etnobotânico para cada espécie, analisando sua finalidade principal, a forma que deve ser manuseada, os riscos que proporciona à saúde e as doses corretas, para impedir a falta de eficácia ou a superdosagem do composto (BADKE et al., 2011). Com análises precisas da funcionalidade medicinal, os resultados servirão de rumo no desenvolvimento de produtos naturais, gerando métodos alternativos no tratamento de algumas doenças.

A Relação Nacional de Plantas Medicinais de Interesse ao Sistema Único de Saúde (RENISUS), criada pelo Ministério da Saúde (MS) em 2009, lista 71 espécies da flora com potencial terapêutico, dando preferência às nativas e que tratam as doenças existentes no país (BRASIL, 2009). Esse programa governamental foi originado da Política e Programa Nacional de Plantas Medicinais e Fitoterápicos, instituída pelo Decreto № 5.813/2006 (BRASIL, 2006), que se compromete em manter a segurança aos usuários e assegurar a utilização racional dessas plantas. Já o Memento Fitoterápico da Farmacopeia Brasileira (ANVISA, 2016) lista as plantas que constam na RENISUS e adiciona informações acerca delas, seus usos, formas de ingestão e possíveis efeitos adversos, baseando-se em 28 monografias que testaram sua eficácia. Juntos, os dois documentos oficiais auxiliam os indivíduos no uso correto e seguro das plantas medicinais.

A Relação Nacional de Medicamentos Essenciais (RENAME) (BRASIL, 2018) listou 12 medicamentos fitoterápicos, sendo estes formulados a partir de algumas espécies medicinais listadas na RENISUS, e que são ofertados gratuitamente à população como forma de incentivo ao seu uso. Visto que existe uma maior procura por tratamentos naturais e o governo está instigando os indivíduos a optarem por este caminho. 0 objetivo deste estudo foi realizar uma revisão bibliográfica sobre o efeito antimicrobiano das plantas que pertencem à lista RENISUS e que constam nessa lista de fitoterápicos do RENAME, a fim de disseminar sua comprovação científica e garantir o conhecimento a respeito de sua eficácia.

\section{METODOLOGIA}

Foram investigadas as plantas medicinais Aloe vera (L.) Burm. f. (babosa), Cynara scolymus L. (alcachofra), Schinus terebinthifolia Raddi. (aroeira), Glycine max (L.) Merr. (isoflavona-de-soja), Harpagophytum procumbens DC. ex Meissn. (garra-do-diabo), Maytenus ilicifolia Mart. ex Reissek (espinheira-santa), Mentha x piperita L. (hortelã), Mikania spp. (guaco), Rhamnus purshiana DC. (cáscarasagrada), Salix alba L. (salgueiro) e Uncaria tomentosa Willd. ex Roem. \& Schult. (unha-de-gato) da RENISUS, 
que são também fitoterápicos da Rename. O gênero Mikania spp., citado nas listas, considera as espécies $M$. glomerata e M. laevigata. Portanto, no momento da pesquisa dos artigos, as duas foram investigadas.

A revisão bibliográfica foi realizada por meio de busca no Portal de Periódicos CAPES, sendo que para cada espécie foram utilizadas como palavras-chave o nome da espécie, por exemplo, 'Glycine max', e o termo 'antimicrobial', filtrando para a busca somente de 'artigos'. A escolha da segunda palavra-chave permite uma maior abrangência de resultados, expandindo para a obtenção de estudos científicos em várias línguas, já que está em língua inglesa. Não foi definida data de publicação específica dos artigos, permitindo um maior número de estudos a serem adicionados para esta revisão; porém, para as espécies que apresentaram elevado número de artigos ou que o sistema apresentou alguma falha na procura, filtrou-se os artigos a partir do ano de criação da RENISUS, em 2009.

Para acessar o artigo completo, foi utilizado o link disposto na base de dados para cada resultado encontrado. Os artigos selecionados foram separados em 12 pastas cada uma com os nomes científicos das plantas consideradas para o estudo. Cada artigo encontrado foi analisado em quatro etapas (leitura do título, leitura do resumo, leitura do texto completo, análise das conclusões). Assim, do número total de estudos para cada espécie, foram selecionados àqueles em que, de acordo com resultados e conclusão dos autores dos estudos, o efeito antimicrobiano foi garantido.

A ordem de etapas da revisão iniciou com a leitura dos títulos dos artigos, verificando se havia alguma relação com a planta em estudo ou com efeito antimicrobiano no geral. Posterior a isso, os resumos de cada estudo foram explorados a fim de filtrar os resultados para a terceira etapa, onde se revisou o texto completo, verificando a metodologia aplicada, os resultados e a conclusão do experimento, para então ser feita a etapa de seleção dos artigos de interesse, onde foram levados em consideração o critério de inclusão.

Como critério de inclusão dos artigos de interesse, consideraram-se todas as metodologias de extração da substância terapêutica da espécie, de qualquer estrutura da planta, em que o passo posterior foi a análise do resultado obtido e verificação da capacidade antimicrobiana. Também, somente os datados a partir do ano de criação da RENISUS, que foi 2009 , foram considerados na análise final. Foram excluídos os artigos de revisão, que indicam o efeito somente ao citar bibliografias ou que mostrem a química da planta e seu uso empírico sem a experimentação. No surgimento de repetição, o artigo é quantificado somente uma vez, registrando a existência de duplicação e o número de estudos repetidos para cada espécie.

\section{RESULTADOS E DISCUSSÃO}

Foram revisados 7.883 artigos da base de dados Periódicos CAPES no processo inicial de busca, o que acarretou a seleção de 459 pela leitura do título. Essa considerável filtragem inicial, onde foram desconsiderados mais de 7.000 artigos, ocorreu devido aos estudos não se enquadrarem nos critérios de inclusão. As etapas seguintes consistiram em analisar os resumos e os artigos completos, onde foram excluídos 306 e 22 estudos, respectivamente. Dos 131 restantes, fez-se a separação pelo período de publicação 'antes de 2009' e 'a partir de 2009', fazendo parte do segundo grupo os artigos de interesse selecionados para a pesquisa, totalizando 97 , ou seja, 1,23\% da quantidade inicial adquirida. A figura 1 
apresenta a ordem de revisão dos artigos e seus respectivos resultados nas etapas para cada planta medicinal.

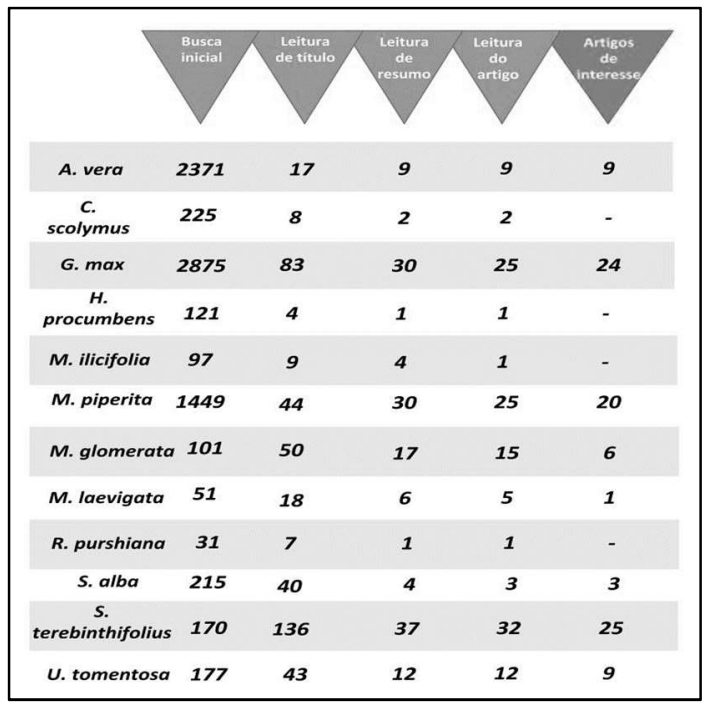

Figura 1: Organograma da seleção dos artigos de interesse de cada planta.

Todas as 12 plantas citadas nas pesquisas foram analisadas a respeito de sua origem, se esta é nativa ou exótica no Brasil. Foi constatado que das 12 , cinco $(41,7 \%)$ plantas são nativas, sendo elas: $M$. ilicifolia, $M$. glomerata, M. laevigata, S. terebinthifolia e U. tomentosa, segundo o site Flora do Brasil 2020 (em construção). O fato de essas plantas serem em menor parte nativas do Brasil ressalta a importância de estudos que explorem a biodiversidade do país, sendo essa a mais rica do planeta e possuir um grande potencial econômico e de interesse tecnológico (BRASIL, 2009).

No sentido de aproveitar esse potencial da biodiversidade brasileira, a Política Nacional de Plantas Medicinais e Fitoterápicos (PNPMF) foi criada, visando o fomento à pesquisa e a inovação de acordo com as necessidades da população. Dentro desse programa, Secretarias Municipais e Estaduais recebem apoio financeiro para a estruturação de três dimensões de projetos, cujos quais são a Assistência farmacêutica em plantas medicinais e fitoterápicos (AF em PMF), Arranjos produtivos locais em plantas medicinais e fitoterápicos (APL) e Desenvolvimento e registro de fitoterápicos da RENAME (DR). No período de 2012 a 2016, 83 projetos foram apoiados, totalizando um valor de aproximadamente R\$31.300.000,00 (BRASIL, 2009).

É possível analisar que as espécies S. terebinthifolia, G. max e M. piperita são as com maior número de publicações com a comprovação do efeito medicinal, sugerindo o sucesso de seu uso em estudos, conforme demonstrado na tabela 1. Almeida et al. (2012) testou extratos de 34 espécies utilizadas na medicina alternativa e constataram o maior efeito antimicrobiano contra Staphylococcus aureus nas espécies S. terebinthifolius e M. piperita. Dentre as 12 espécies, C. scolymus, H. procumbens, M. ilicifolia e R. purshiana não foram constadas nos artigos selecionados, demonstrando a necessidade por atualizações científicas a respeito de sua atividade antimicrobiana, uma vez que em artigos excluídos foram citadas. 
Tabela 1: Artigos de interesse com suas respectivas características.

\begin{tabular}{|c|c|c|c|}
\hline Parte da planta & Tipo de estudo/Metodologia & Principais resultados & Referência \\
\hline \multicolumn{4}{|l|}{ Aloe vera $\mathrm{L}$. } \\
\hline $\begin{array}{l}\text { Gel fresco da parte } \\
\text { mucilaginosa da } \\
\text { folha }\end{array}$ & $\begin{array}{l}\text { In vitro. Teste com diferentes concentrações do gel em } \\
\text { dois fungos (Penicillium digitatum e Botrytis cinerea), } \\
\text { presentes em placas com ágar dextrose de batata } \\
\text { (PDA), analisando-se assim seu crescimento e } \\
\text { desenvolvimento através do diâmetro do micélio. }\end{array}$ & $\begin{array}{l}\text { Em todas concentrações do gel houve um efeito } \\
\text { inibitório de desenvolvimento dos fungos. Os } \\
\text { melhores efeitos antifúngicos apareceram em } P \text {. } \\
\text { digitatum, mostrando que sua eficácia depende } \\
\text { da espécie a ser combatida. }\end{array}$ & $\begin{array}{l}\text { Castillo et al. } \\
\text { (2010) }\end{array}$ \\
\hline $\begin{array}{l}\text { Gel fresco da parte } \\
\text { mucilaginosa da } \\
\text { folha }\end{array}$ & $\begin{array}{l}\text { In vitro. Adição do gel da planta a seis fungos } \\
\text { (Fusarium oxysporum, Alternaria alternate, } \\
\text { Colletrotrichum gloesporoides, Bipolaris spicifera, } \\
\text { Curvularia hawaiiensis e Botryotinia fuckeliana), } \\
\text { presentes em placas com ágar PDA, analisando-se } \\
\text { assim seu crescimento e desenvolvimento através do } \\
\text { diâmetro do micélio. A Inibição de Crescimento de } \\
\text { Micélio foi calculada. }\end{array}$ & $\begin{array}{c}\text { Grande inibição do crescimento do micélio em } \\
\text { todas placas com fungos que foi adicionado o gel } \\
\text { de } A \text {. vera, porém, fortemente observada em } F \text {. } \\
\text { oxysporum, B. spiciferae e } C \text {. hawaiiensis. O } \\
\text { menor efeito inibitório fori observado contra } C \text {. } \\
\text { gloesporoides. }\end{array}$ & $\begin{array}{l}\text { Ortega-Toro et } \\
\text { al. (2017) }\end{array}$ \\
\hline $\begin{array}{c}\text { Suco de Aloe vera } \\
\text { puro (grau } \\
\text { farmacêutico) }\end{array}$ & $\begin{array}{l}\text { In vitro. Comparação de tecidos de seda, com e sem } \\
\text { contaminação por bactérias. Feito um meio com BTCA } \\
\text { e SHP, e suco de } A \text {. vera, onde mergulhou-se a seda } \\
\text { por } 30 \text { minutos no licor, em um copo. O tecido foi } \\
\text { espremido e secado, lavado com solução a } 30^{\circ} \mathrm{C} \text {, } \\
\text { seguido de água fria para remover outras químicas. As } \\
\text { propriedades antimicrobianas foram analisadas pelo } \\
\text { método AATCC } 147 \text { (qualitativo) e AATCC } 100 \\
\text { (quantitativo), contra Staphylococcus aureus (gram- } \\
\text { positivo) e Klesbsiella pneumonia (gram-negativo), } \\
\text { calculando-se o percentual de redução das espécies e } \\
\text { nivelando para \% acima de } 99 \text { como nível avançado. }\end{array}$ & $\begin{array}{l}\text { No tecido de seda sem tratamento não houve } \\
\text { redução na contagem de bactérias, } \\
\text { demonstrando que não tem propriedade } \\
\text { antimicrobiana naturalmente. A melhor atividade } \\
\text { antimicrobiana ocorreu no tecido de seda tratado } \\
\text { com o licor de } A \text {. vera a } 15 \% \text { de concentração, } \\
\text { além de demonstrar maior durabilidade do } \\
\text { tratamento comparando com as outras } \\
\text { concentrações do meio. }\end{array}$ & $\begin{array}{l}\text { Nadiger et al. } \\
\qquad(2015)\end{array}$ \\
\hline $\begin{array}{l}\text { Dentifrício de Aloe } \\
\text { vera }\end{array}$ & $\begin{array}{l}\text { In vitro. Escovação, cada uma por um min., em cinco } \\
\text { grupos de dentição bovina: GI com contaminação e } \\
\text { sem dentifrício (controle negativo); GII: contaminação } \\
\text { e com dentifrício fluoretado; GIII: contaminação e com } \\
\text { dentifrício de triclosan e gantrez; GIV: contaminação } \\
\text { sem dentifrício, porém, com irrigação de } 10 \mathrm{~mL} \text { de } \\
\text { gluconato de clorexidina (controle positivo); GV: } \\
\text { contaminação e com dentifrício de } A \text {. vera e própolis } \\
\text { de abelha. A contaminação foi por Streptococcus } \\
\text { mutans. }\end{array}$ & $\begin{array}{l}\text { Há significante diferença estatística da redução } \\
\text { do contaminante comparando os grupos II, III, IV } \\
\text { e V com o I. O dentifrício de } A \text {. vera com própolis } \\
\text { também reduziu a concentração de bactérias, } \\
\text { porém não obteve diferença significativa entre os } \\
\text { outros grupos que surtiram o mesmo efeito. }\end{array}$ & $\begin{array}{l}\text { Bertolini et al. } \\
\qquad(2010)\end{array}$ \\
\hline $\begin{array}{l}\text { Gel fresco da parte } \\
\text { mucilaginosa da } \\
\text { folha }\end{array}$ & $\begin{array}{c}\text { In vitro. Preparou-se o extrato hidroalcoólico de } A \text {. } \\
\text { vera e Punica granatum em concentrações de } 5,25,50 \\
\text { e } 100 \% \text {. S. mutans foi isolado em ágar MSB, } \\
\text { adicionando-se os extratos de } A \text {. vera, romã e sorbitol } \\
\text { (controle negativo) nas placas de Petri. Foi observado } \\
\text { o efeito das diferentes concentrações para cada } \\
\text { extrato e feita análise estatística. }\end{array}$ & $\begin{array}{l}\text { Houve uma inibição significativa da bactéria para } \\
\text { o teste com } A \text {. vera, porém, o maior efeito } \\
\text { antimicrobiano ocorreu no extrato de } P \text {. } \\
\text { granatum, em todas concentrações. }\end{array}$ & $\begin{array}{l}\text { Subramaniam } \\
\text { et al. (2012) }\end{array}$ \\
\hline $\begin{array}{l}\text { Gel fresco da parte } \\
\text { mucilaginosa da } \\
\text { folha }\end{array}$ & $\begin{array}{l}\text { In vitro. O extrato foi encapsulado em TG, formando } \\
\text { nanocápsulas, pelo método de microemulsão baseada } \\
\text { em sonoquímica. Foram utilizadas as bactérias } \\
\text { Escherichia coli (gram-negativa), S. aureus (gram- } \\
\text { positiva) e o fungo Candida albicans. Os } \\
\text { microrganismos foram preparados pelo método ASTM } \\
\text { E2149-01, de Shake-flash. }\end{array}$ & $\begin{array}{l}\text { Foi observada uma redução antimicrobiana de } 84, \\
91 \text { e } 80 \% \text { para } E \text {. coli, S. aureus e C. albicans, } \\
\text { confirmando grande efeito antimicrobiano da } \\
\text { planta, seja bactéria ou fungo. }\end{array}$ & $\begin{array}{l}\text { Ghayempour } \\
\text { et al. (2016) }\end{array}$ \\
\hline $\begin{array}{l}\text { Gel fresco da parte } \\
\text { mucilaginosa da } \\
\text { folha }\end{array}$ & $\begin{array}{l}\text { In vitro. Frutos do mamão-papaia frescos foram } \\
\text { envolvidos pelo gel da planta ( } 50 \% \text { ) (AG), extrato das } \\
\text { folhas do mamão tiveram incorporação com o gel de } \\
\text { A. vera (PLEAG) ( } 1: 1 \text { ) e } 2,5 \% \text { de quitosana, sendo que o } \\
\text { grupo negativo não teve o fruto revestido pelos } \\
\text { compostos. Todos frutos foram armazenados a +- } 30^{\circ} \mathrm{C} \\
\text { e com } 42-55 \% \text { de } \mathrm{RH} \text { por } 15 \text { dias. Foram analisadas as } \\
\text { características físicas (PLW, tamanho do fruto), } \\
\text { químicas ( } \mathrm{pH} \text {, acidez titulável e TSS) e sensoriais (cor, } \\
\text { sabor, firmeza). }\end{array}$ & $\begin{array}{l}\text { Os frutos revestidos com os meios sobreviveram } \\
\text { os } 15 \text { dias, porém, o grupo controle durou até } 10 \\
\text { dias, demonstrando mudanças em todos } \\
\text { parâmetros testados, incluindo contaminação } \\
\text { fúngica. Dentre os frutos com o revestimento, o } \\
\text { melhor efeito (de manter as características totais } \\
\text { do mamão) foram PLEAG, seguido de AG e } \\
\text { quitosana, podendo confirmar que o uso de } A \text {. } \\
\text { vera impede a formação de microorganismos no } \\
\text { período que envolve a colheita do mamão até ser } \\
\text { consumido pelo comprador. }\end{array}$ & $\begin{array}{l}\text { Marpudi et al. } \\
\qquad(2011)\end{array}$ \\
\hline
\end{tabular}




\begin{tabular}{|c|c|c|c|}
\hline Parte da planta & Tipo de estudo/Metodologia & Principais resultados & Referência \\
\hline $\begin{array}{l}\text { Gel fresco da parte } \\
\text { mucilaginosa da } \\
\text { folha }\end{array}$ & $\begin{array}{l}\text { In vitro. Foram feitas triplicatas usando a difusão de } \\
\text { um disco vazio com ágar Mueller-Hinton. O inócuo } \\
\text { com quatro bactérias ( } S \text {. mutans, S. aureus, } \\
\text { Aggregatibacter actinomycetemcomitans, } \\
\text { Enterococcus faecalis) e um fungo (C. albicans) foi } \\
\text { preparado em suspensões padronizadas de } 0,5 \\
\text { MacFarland. Foram feitos grupos experimentais [ } A \text {. } \\
\text { vera (AV), } A \text {. vera com amoxicilina (AMX), } A \text {. vera com } \\
\text { nistatina (NYS)] e controle], mantendo em } \\
\text { temperatura adequada (bactérias } 35^{\circ} \mathrm{C} \text { e fungo } 37^{\circ} \mathrm{C} \text { ) } \\
\text { por } 24 \text { horas, obtendo os resultados medindo o } \\
\text { diâmetro dos locais inibidos ao redor dos discos, com } \\
\text { uso do halômetro e ANOVA e Turkey para análise. }\end{array}$ & $\begin{array}{l}\text { O maior efeito surtiu em AMX. S. aureus, } S \text {. } \\
\text { mutans, A. actinomycetemcomitans e } E \text {. faecalis } \\
\text { apresentaram sensibilidade somente nesse grupo } \\
\text { experimental, mas para as duas primeiras sem } \\
\text { diferença do grupo controle. Já as duas últimas } \\
\text { têm significativa diferença do grupo controle. } \\
\text { Para } C \text {. albicans, o efeito antimicrobiano ocorreu } \\
\text { semelhante ao grupo controle para NYS. }\end{array}$ & $\begin{array}{c}\text { Gontijo et al. } \\
\qquad(2013)\end{array}$ \\
\hline Folha & $\begin{array}{c}\text { In vitro. Foram feitos os extratos de Neem e } A \text {. vera, } \\
\text { onde verificou-se a concentração inibitória } \\
\text { antimicrobiana contra } E \text {. faecalis e } C \text {. albicans, } \\
\text { comparando com } 3 \% \mathrm{NaOCl} \text { e } 2 \% \mathrm{CHX} \text {, no método } \\
\text { difusão de ágar-poço. }\end{array}$ & $\begin{array}{c}\text { Constatou-se que o extrato de } A \text {. vera a } 1,88 \% \text { de } \\
\text { concentração apresentou melhor eficácia contra } \\
\text { E. faecalis e a } 3,88 \% \text { contra } C \text {. albicans } \\
\text { comparando com } 3 \% \mathrm{NAOCl} \text { e } 2 \% \mathrm{CHX} \text {. } \\
\text { Estatisticamente, houve uma significativa } \\
\text { diferença entre os grupos testados e dentro dos } \\
\text { grupos. }\end{array}$ & $\begin{array}{l}\text { Prasad et al. } \\
\qquad(2016)\end{array}$ \\
\hline \multicolumn{4}{|c|}{ Glycine max (L.) Merr. } \\
\hline $\begin{array}{l}\text { Isolamento gênico } \\
\text { de um cultivar da } \\
\text { soja com alta } \\
\text { resistência contra } \\
\text { P. sojae. }\end{array}$ & $\begin{array}{l}\text { In vitro. P. sojae cresceu em placas de ágar suco V8 até } \\
\text { a colônia alcançar } 3,5 \mathrm{~cm} \text { de diâmetro, onde se } \\
\text { adicionou papel filtro estéril a } 1 \mathrm{~cm} \text { da frente do } \\
\text { crescimento e aplicou-se } 15 \text { a } 25 \mu \mathrm{g} \text { da proteína Gly } 4 \\
\mathrm{ml} \text { do gene da soja isolado. Grupo controle com buffer } \\
\text { ou proteína fervida. Manteu-se a } 25^{\circ} \mathrm{C} \text { por } 24 \mathrm{~h} \text { e } \\
\text { mediu-se as zonas de crescimento das hifas do } \\
\text { patógeno. Também foram desenvolvidos os zoósporos } \\
\text { do fungo, onde foram retiradas } 10 \text { colônias, feitas as } \\
\text { trocas de água estéril ( } 4 \text { vezes) para desenvolvimento } \\
\text { e por último adicionada a proteína, incubando por } 16 \mathrm{~h} \\
\text { no escuro. }\end{array}$ & $\begin{array}{l}\text { Após } 72 \mathrm{~h} \text { foram registradas zonas de inibição de } \\
2-3 \mathrm{~mm} \text { e } 4-6 \mathrm{~mm} \text {, com } 15 \text { e } 25 \mu \mathrm{g} \text { da proteína Gly } \\
4 \mathrm{ml} \text {, respectivamente. No controle a inibição não } \\
\text { ocorreu. Contra os zoósporos, a proteína } \\
\text { apresentou efeito antimicrobiano, onde } \\
\text { apresentou significativo decréscimo deles pela } \\
\text { adição de } 100 \mu \mathrm{g} \text { da proteína comparando com o } \\
\text { resultado do controle. }\end{array}$ & $\begin{array}{l}\text { Fan et al. } \\
(2015)\end{array}$ \\
\hline $\begin{array}{l}\text { Sementes de duas } \\
\text { variedades } \\
\text { mutantes (M7 e } \\
\text { M9) }\end{array}$ & $\begin{array}{l}\text { In vitro. As sementes foram secadas, lavadas, } \\
\text { desinfetadas e armazenadas em temperatura } \\
\text { ambiente para depois ser feita a extração. O método } \\
\text { aplicado foi difusão de disco simples para bactérias, } \\
\text { em diferentes concentrações do extrato de G. max M7 } \\
\text { e M9 ( } 25,50 \text { e } 100 \mathrm{mg} / \mathrm{mL} \text { ). Discos de papel com } 10 \mu \mathrm{g} \\
\text { (de cada concentração) foram postos na camada } \\
\text { superior das placas. Os resultados foram comparados } \\
\text { com o efeito de diferentes agentes antibióticos, como } \\
\text { ciprofloxacin, penicilina G, tetraciclina, gentamicina e } \\
\text { azitromicina. No grupo controle utilizou-se água } \\
\text { destilada em todas reações. }\end{array}$ & $\begin{array}{l}\text { Os diâmetros das zonas de inibição, entre M7 e } \\
\text { M9 foram de aproximadamente 5,93 a 22,61mm. } \\
\text { A variedade da soja M7 apresentou melhores } \\
\text { efeitos antimicrobianos que M9. O maior } \\
\text { diâmetro de inibição alcançado em M7 foi da } \\
\text { bactéria Listeria monocytogenes e S. aureus, na } \\
\text { concentração de 100mg/mL. Para os antibióticos, } \\
\text { a zona de inibição foi do diâmetro 5,94 a } 24,95 \\
\text { aproximadamente, pouco maior que da planta. }\end{array}$ & $\begin{array}{c}\text { Chaleshtori et } \\
\text { al. (2017) }\end{array}$ \\
\hline Cascos da semente & $\begin{array}{l}\text { In vitro. Foram feitos os extratos fenólicos dos cascos } \\
\text { das sementes de G. max amarela, marrom-escuro, } \\
\text { marrom e preto, aplicando contra Salmonella } \\
\text { Typhimurium, E. coli e Campylobacter jejuni em } \\
\text { culturas de caldo e também com pele de galinha. No } \\
\text { primeiro método foram testadas diferentes } \\
\text { concentrações do extrato fenólico }(0,5 ; 1,0 ; 2,0 ; 6,0 ; \\
\text { 10,0\%), por tempos diferentes de incubação }(1,3 \text { e } 6 \\
\text { dias), analisando a redução log das colônias. }\end{array}$ & $\begin{array}{c}\text { O efeito antimicrobiano em culturas de caldo foi } \\
\text { mais eficaz com a concentração de } 10 \% \text { nos três } \\
\text { períodos de tempo contra todas bactérias. Em } \\
\text { nenhuma concentração houve eficácia nas } \\
\text { primeiras } 24 \mathrm{~h} \text {. Ao testar na pele de galinha, } \\
\text { houve pigmentação da pele com as maiores } \\
\text { concentrações, utilizando para o teste a menor e } \\
\text { a maior que não causassem coloração ( } 0,5 \text { e } 2 \%) \text {. } \\
\text { A concentração } 2 \% \text { demonstrou efeito } \\
\text { antibacteriano melhor, para } 3 \text { a } 6 \text { dias de } \\
\text { incubação. }\end{array}$ & $\begin{array}{l}\text { Abutheraa et } \\
\text { al. (2017) }\end{array}$ \\
\hline Óleo de soja & $\begin{array}{l}\text { In vitro. Foram preparadas } 5 \text { emulsões (N1, N2, N3, N4 } \\
\text { E N5) e testadas, para cada uma, sua Concentração } \\
\text { Inibitória Mínima (MIC) e Concentração Bactericida } \\
\text { Mínima (MBC) contra a bactéria A. baumannii. }\end{array}$ & $\begin{array}{l}\text { As emulsões N1, N2, N3 e N4 não mostraram } \\
\text { nenhum efeito antibacteriano, sendo N5 a única } \\
\text { que obteve em } 4 \text { cepas, tanto para MIC quanto } \\
\text { para MBC, com bactéria na forma planctônica e } \\
\text { biofilme. Essa emulsão é composta pelas } \\
\text { substâncias } 10 \% \text { Triton X-100 (presente em todas } \\
\text { emulsões), 25\% de óleo de soja (segunda menor } \\
\text { concentração) e 1\% de Cloreto de Cetilpiridínio } \\
\text { (CPC). Apesar do CPC ser o responsável pela } \\
\text { morte das bactérias em forma planctônica, a } \\
\text { degradação dos biofilmes ocorreu devido às } \\
\text { frações emulsificadas de óleo e detergente. }\end{array}$ & $\begin{array}{l}\text { Hwang et al. } \\
\qquad(2013)\end{array}$ \\
\hline
\end{tabular}




\begin{tabular}{|c|c|c|c|}
\hline Parte da planta & Tipo de estudo/Metodologia & Principais resultados & Referência \\
\hline Semente & $\begin{array}{l}\text { In vitro. As sementes de feijão, soja e grão-de-bico } \\
\text { foram lavadas, desengorduradas, alterou-se pH e feita } \\
\text { centrifugação. Ao final, a proteína desejada precipitou } \\
\text { e foi preparada com lavagens, dialisada à noite, } \\
\text { liofilisada e esterificada. Feito ensaio de disco contra } \\
\text { as bactérias Gram-positivas (Bacillus subtilis, S. aureus) } \\
\text { e Gram-negativas (E. coli, Pseudomonas aeruginosa), } \\
\text { adicionando } 3 \text { diferentes concentrações ( } 0,1 ; 1 \text { e } \\
10 \mathrm{mg} / \mathrm{mL} \text { ) das proteínas metiladas das plantas nos } \\
\text { discos de Petri com ágar. O grupo controle foi feito } \\
\text { com água destilada no lugar da proteína. }\end{array}$ & $\begin{array}{c}\text { Nenhum controle apresentou zonas de inibição } \\
\text { bacteriana. As proteínas adicionadas } \\
\text { apresentaram o efeito inibitório, mas verificou-se } \\
\text { que dependem da concentração utilizada. Para a } \\
\text { soja surgiram pequenas diferenças de inibição } \\
\text { entre as Gram-positivas e Gram-negativas, onde } \\
\text { em cada grupo de bactérias, uma foi mais inibida } \\
\text { que a outra, o que não ocorreu com as proteínas } \\
\text { do feijão e grão-de-bico. }\end{array}$ & $\begin{array}{l}\text { Sitohy et al. } \\
(2010)\end{array}$ \\
\hline $\begin{array}{c}\text { Soja crua, farinha } \\
\text { de soja e soja } \\
\text { torrada }\end{array}$ & $\begin{array}{l}\text { In vitro. Dos materiais da soja fez-se extrações sólido- } \\
\text { líquidas modificadas para isolar os componentes } \\
\text { inibitórios, e assim, obtiveram-se extratos que foram } \\
\text { adicionados contra as bactérias em diferentes } \\
\text { concentrações sob diversas soluções extraídas ( } 75 ; 50 ; \\
25 ; 12,5 ; 6,25 \text { e } 3,125 \% \text { ). Foi então testada a ação } \\
\text { inibitória contra a bactéria } E \text {. coli e } S \text {. aureus pelo } \\
\text { método de difusão em disco, além da MIC. }\end{array}$ & $\begin{array}{l}\text { O melhor desempenho foi com farinha de soja, } \\
\text { com MIC dos compostos inibitórios de maior } \\
\text { porcentagem em soja crua ( } 50 \% \text { ), sendo que } \\
\text { farinha e soja torrada ficaram com } 6,25 \text { e } 25 \% \text { de } \\
\text { inibição, respectivamente. A inibição no geral, } \\
\text { dentre os } 3 \text { materiais, foi mais eficaz para } E \text {. coli } \\
\text { que S. aureus. Notou-se melhor desempenho } \\
\text { para os extratos brutos de farinha de soja e soja } \\
\text { torrada que ela in natura. }\end{array}$ & $\begin{array}{l}\text { Laodheerasiri } \\
\text { et al. (2017) }\end{array}$ \\
\hline Semente & $\begin{array}{l}\text { In vitro. Foram obtidos } 4 \text { genótipos (Rawal-I, NARC-II, } \\
\text { SA-72-60 e Ajmeri,) de variedades da planta para } \\
\text { analisar a capacidade antimicrobiana pelo método de } \\
\text { ensaio de difusão em ágar, em que três tipos de } \\
\text { extratos (aquoso, metanol e peptídeo) foram } \\
\text { preparados do pó das sementes. As bactérias para a } \\
\text { pesquisa são Streptomyces laurentii, Enterococcus } \\
\text { faecium, Microbacterium oxydans, Pseudomonas } \\
\text { geniculata, Alcaligenes faecalis, K. pneumoniae e B. } \\
\text { subtilis. }\end{array}$ & $\begin{array}{l}\text { Os genótipos Rawal-I e NARC-II exibiram o efeito } \\
\quad \text { antimicrobiano máximo nas maiores } \\
\text { concentrações dos extratos contra S. laurentii, e } \\
\text { P. geniculata, enquanto os outros dois genótipos } \\
\text { foram ineficazes contra todas cepas da pesquisa. }\end{array}$ & $\begin{array}{c}\text { Ain et al. } \\
(2017)\end{array}$ \\
\hline Farinha de soja & $\begin{array}{l}\text { In vitro. Para a atividade antimicrobiana, foram } \\
\text { adicionados } 20 \% \text { de água nas soluções e posta em um } \\
\text { evaporador para obter a quantidade concentrada do } \\
\text { extrato fenólico aquoso (APE), usando contra } \\
\text { patógenos alimentares pelos métodos ensaio de } \\
\text { microdiluição em caldo e diluição em ágar. Foram } \\
\text { adicionadas diferentes concentrações de APE em } \\
\text { pêssegos com e sem o fungo Monilia laxa, tendo o } \\
\text { grupo controle com a adição de água esterilizada. }\end{array}$ & $\begin{array}{l}\text { A maior atividade antibacteriana foi contra } L \text {. } \\
\text { monocytogenes, } B \text {. cereus e } E \text {. faecalis, com } \\
\text { valores de } 50 \% \text { de inibição, mesmo nas menores } \\
\text { concentrações do extrato. Detectou-se que } \\
\text { bactérias Gram-positivas são mais sensíveis ao } \\
\text { APE que as Gram-negativas. O efeito inibitório de } \\
\text { APE contra fungos foi muito menor que contra } \\
\text { bactérias. Fungos Torulaspora spp., Cryptococcus } \\
\text { spp. e Rhodotorula spp. tiveram sua atividade } \\
\text { diminuída em concentrações mais baixas de APE. }\end{array}$ & $\begin{array}{l}\text { Villalobos et } \\
\text { al. (2015) }\end{array}$ \\
\hline $\begin{array}{c}\text { Farinha de soja } \\
\text { com baixo teor de } \\
\text { gordura }\end{array}$ & $\begin{array}{l}\text { In vitro. Foram adquiridas as isoflavonas de soja } \\
\text { realizando-se o estudo antimicrobiano contra } \\
\text { biofilmes de L. monocytogenes, E. coli, P. aeruginosa e } \\
\text { S. aureus resistente (MRSA), por ensaios de placa de } \\
\text { microtitulação (MPAs) (para o efeito antimicrobiano), } \\
\text { microscopia eletrônica de varredura (SEM) e } \\
\text { microscopia de força atômica (AFM). }\end{array}$ & $\begin{array}{c}\text { Da parte antimicrobiana foi detectado que a } \\
\text { farinha de soja foi eficaz contra as bactérias } L \text {. } \\
\text { monocytogenes (reduziu sua biomassa) e } E \text {. coli } \\
\text { em concentrações de } 10 \text { e } 100 \mathrm{mg} / \mathrm{mL} \text {, porém, } \\
\text { sem efeito inibitório contra biofilmes de MRSA e } \\
\text { P. aeruginosa. }\end{array}$ & $\begin{array}{c}\text { Dhayakaran et } \\
\text { al. (2015) }\end{array}$ \\
\hline Semente & $\begin{array}{l}\text { In vitro. Extraiu-se o óleo essencial, sendo submetido } \\
\text { ao teste antimicrobiano pelo método de difusão de } \\
\text { disco, MIC contra os fungos Pyricularia oryzae, } F \text {. } \\
\text { oxysporum, Sclerotinia sclerotiorum, A. alternata, B. } \\
\text { cinerea e Rhizoctonia solani, e MBC contra oito } \\
\text { bactérias (B. subtilis, S. aureus, Rathayibacter toxicus, } \\
\text { E. coli, P. aeruginosa, } P \text {. syringae subsp. syringae, } P \text {. } \\
\text { viridiflava e Xanthomonas campestris pv. Campestris). }\end{array}$ & $\begin{array}{l}\text { A maior atividade antimicrobiana ocorreu contra } \\
\text { as espécies } R \text {. toxicus e } P \text {. syringae subsp. } \\
\text { syringae, seguida de } S \text {. aureus, } B \text {. subtilis e } E \text {. coli. } \\
\text { Não houve nenhum efeito inibitório contra } \\
\text { P.aeruginosa, } P \text {. viridiflava, e } X \text {. campestris pv. } \\
\text { Campestris. Dos resultados de MIC, a maior } \\
\text { atividade antifúngica foi observada em } P \text {. oryzae, } \\
\text { seguida de } S \text {. sclerotiorum, } F \text {. oxysporum, B. } \\
\text { cinerea, } A \text {. alternata e } R \text {. solani. }\end{array}$ & $\begin{array}{c}\text { Ghahari et al. } \\
\text { (2017) }\end{array}$ \\
\hline Semente & $\begin{array}{l}\text { In vitro. Sementes foram esterilizadas, enxaguadas em } \\
\text { três períodos e postas para germinar em ambiente } \\
\text { escuro por } 4 \text { dias. O micélio do patógeno } P \text {. sojae foi } \\
\text { cultivado em ágar nas placas de Petri por } 2 \text { dias a } 25 \text { o C } \\
\text { e depois descontaminados. Hipocótilos de plântulas de } \\
\text { soja foram inoculados com o patógeno e incubados, } \\
\text { mantidos por } 12 \text { a } 24 \text { h no escuro. Após, foram } \\
\text { recolhidos e utilizados para análise. O controle foi o } \\
\text { hipocótilo sem a adição do patógeno. Por fim, } \\
\text { proteínas foram extraídas para a análise } \\
\text { antimicrobiana por eletroforese em gel bidimensional. }\end{array}$ & $\begin{array}{l}\text { Foram expressas } 95 \text { manchas de proteínas, sendo } \\
\text { que } 83 \text { foram identificadas com sucesso e } \\
\text { submetidas à análise adicional. A maioria das } 83 \\
\text { proteínas apresentaram resposta de defesa. Com } \\
\text { a técnica de inserção do fungo, surgiram várias } \\
\text { espécies reativas ao oxigênio (ROS) e os níveis de } \\
\text { expressão de ácido salicílico (SA) aumentaram, } \\
\text { além de elevar níveis de isoflavonas, sugerindo } \\
\text { que ROS e SA desempenham papel importante ao } \\
\text { sistema de defesa da planta. }\end{array}$ & $\begin{array}{l}\text { Jing et al. } \\
(2015)\end{array}$ \\
\hline
\end{tabular}




\begin{tabular}{|c|c|c|c|}
\hline Parte da planta & Tipo de estudo/Metodologia & Principais resultados & Referência \\
\hline Semente & $\begin{array}{l}\text { In vitro. Comparou-se a ação das proteínas da soja } \\
\text { com as do leite de soja. As sementes de soja foram } \\
\text { lavadas, secas e moídas. O pó que restou foi } \\
\text { desengordurado e o pellet foi tratado com tampão de } \\
\text { extração de proteína. Amostras foram incubadas e } \\
\text { centrifugadas para que o sobrenadante fosse diluído } \\
\text { em } 4 \text { volumes. Para a atividade, foi feita uma } \\
\text { simulação da digestão gastrointestinal e } \\
\text { processamento de dados por bioinformática. As } \\
\text { proteínas foram quantificadas pelo método Bradford. }\end{array}$ & $\begin{array}{l}\text { A degradação da proteína da soja na digestão } \\
\text { gastrointestinal simulada gerou grande } \\
\text { quantidade de peptídeos (1173), alguns de } \\
\text { atividade biológica estabelecida e outras com } \\
\text { atividade antimicrobiana prevista. As proteínas } \\
\text { do leite apresentaram maiores quantidades de } \\
\text { peptídeos (1364 para leite de soja não tratado e } \\
1422 \text { para leite de soja em que proteínas foram } \\
\text { extraídas por precipitação). }\end{array}$ & $\begin{array}{c}\text { Capriotti et al. } \\
\text { (2015) }\end{array}$ \\
\hline $\begin{array}{l}\text { Soja fermentada } \\
\text { tradicional } \\
\text { tailandesa }\end{array}$ & $\begin{array}{l}\text { In vitro. Da atividade antimicrobiana, a amostra } \\
\text { liofilizada passou por processo de agitação com } \\
\text { metanol para a extração do pó moído da amostra de } \\
\text { soja. Os extratos foram filtrados, concentrados e } \\
\text { testados contra S. aureus, S. epidermidis, Micrococcus } \\
\text { luteus, B. cereus, E. coli, P. aeruginosa, S. } \\
\text { Typhimurium, Enterobacter aerogenes, C. albicans, C. } \\
\text { famata, C. glabrata, Saccharomyces cerevisiae, S. } \\
\text { ellipsoideus, L. monocytogenes e S. enteritidis. O } \\
\text { método foi difusão do disco de papel. Para observação } \\
\text { de resultados levou-se em conta a Magnitude Relativa } \\
\text { de Inibição (RMI) calculada com a razão da área entre } \\
\text { zona inibida e zona do controle negativo. }\end{array}$ & $\begin{array}{c}\text { Da parte antimicrobiana, apenas as bactérias } \\
\text { Gram-positivas foram inibidas pelo extrato } \\
\text { metanólico de thua nao, dentre elas } S \text {. aureus, } S \text {. } \\
\text { epidermidis, } M \text {. luteus, } B \text {. cereus e } L \text {. } \\
\text { monocytogenes. }\end{array}$ & $\begin{array}{l}\text { Dajanta et al. } \\
\text { (2012) }\end{array}$ \\
\hline Semente & $\begin{array}{l}\text { In vitro. Foram obtidas subunidades proteicas para } \\
\text { testar a atividade antimicrobiana. Método por ensaio } \\
\text { de difusão em ágar contra os patógenos } L \text {. } \\
\text { monocytogenes, } S \text {. enteritidis e } B \text {. subtilis. As culturas } \\
\text { puras dos patógenos foram subcultivadas em caldo } \\
\text { MHB sendo adicionadas diferentes concentrações ( } 0 \text {, } \\
25,50,100,250,500 \text { e } 1000 \mu \mathrm{g} / \mathrm{mL} \text { ) para observar } \\
\text { posteriormente a MIC. Tubos de controle foram feitos } \\
\text { sem a adição da proteína antimicrobiana, e sim com o } \\
\text { uso da penicilina. }\end{array}$ & $\begin{array}{l}\text { Três porções de proteína inibiram as três } \\
\text { bactérias do estudo. À medida que a } \\
\text { concentração do antimicrobiano foi aumentando, } \\
\text { a zona de inibição foi crescendo. A MIC iniciou } \\
\text { com a concentração de } 100 \mu \mathrm{g} / \mathrm{mL} \text {, indicando que } \\
\text { a ação antibacteriana começa com baixas } \\
\text { concentrações já, no mesmo nível da penicilina. }\end{array}$ & $\begin{array}{l}\text { Sitohy et al. } \\
\text { (2012) }\end{array}$ \\
\hline Semente & $\begin{array}{l}\text { In vitro. Foi extraído o óleo das sementes das plantas } \\
\text { Cocos nucifera, Helianthus annus, Brassica juncea, } \\
\text { Ricinus communis, Arachis hypogea, G. max, } \\
\text { Gossypium hirsutum e Sesamum indicum para avaliar a } \\
\text { atividade antimicrobiana usando o método de difusão } \\
\text { em ágar e a MIC. Os patógenos utilizados na pesquisa } \\
\text { foram E. coli, Trichophyton rubrum e C. albicans. }\end{array}$ & $\begin{array}{l}\text { Todos óleos apresentaram potencial } \\
\text { antimicrobiano contra todos patógenos, porém, a } \\
\text { planta } H \text {. annus apresentou máxima atividade } \\
\text { inibitória, seguida de } R \text {. communis, } C \text {. nucifera, } B \text {. } \\
\text { juncea, S. indicum, G. hirsutum, G. max e } A . \\
\text { hypogea. }\end{array}$ & $\begin{array}{c}\text { Tabassum et } \\
\text { al. (2014) }\end{array}$ \\
\hline $\begin{array}{l}\text { Extrato aquoso da } \\
\text { planta }\end{array}$ & $\begin{array}{l}\text { In vitro. O extrato aquoso de G. max e Vaccinium } \\
\text { macrocarpon foram adquiridos, além de outras } \\
\text { combinações de extratos, e aplicou-se o método de } \\
\text { determinação da MIC e Concentração Citotóxica } \\
\text { Mínima (MCC) para a verificação de atividade } \\
\text { antimicrobiana na adesão e invasão de P. aeruginosa. } \\
\text { Para tal, foram utilizadas células de pulmão, onde cada } \\
\text { extrato foi adicionado (Controle, Ciprofloxacina, } \\
\text { Dextran, Ciprofloxacina+Dextran, Extrato de soja, } \\
\text { Ciprofloxacina+Extrato de soja, Cranberry e } \\
\text { Ciprofloxacina+Cranberry) na célula, seguido da adição } \\
\text { do patógeno. }\end{array}$ & $\begin{array}{l}\text { Todos os extratos apresentaram uma redução } \\
\text { significativa na adesão e invasão do patógeno na } \\
\text { célula em relação ao controle. }\end{array}$ & $\begin{array}{l}\text { Ahmed et al. } \\
\qquad(2014)\end{array}$ \\
\hline Vagem & $\begin{array}{l}\text { In vitro. Analisou-se MIC contra cinco bactérias, duas } \\
\text { Gram-positivas (S. aureus e E. faecium) e três Gram- } \\
\text { negativas ( } P \text {. aeruginosa, S. pneumoniae e E. coli). As } \\
\text { bactérias foram cultivadas em ágar MH e incubadas, } \\
\text { adicionando as isoflavonas da soja (total de } 9 \text { ) e } \\
\text { verificando a ação posteriormente (método de } \\
\text { diluição de tubo). Foram feitas triplicatas para cada } \\
\text { teste. Para analisar se a diferença foi significativa, } \\
\text { utilizou-se o sistema ANOVA. }\end{array}$ & $\begin{array}{l}\text { De nove componentes do estudo, apenas dois } \\
\text { apresentaram efeito inibitório contra as cinco } \\
\text { bactérias, que apresentaram valores MIC bem } \\
\text { baixos ( } 10.6 \text { to } 22.6 \mu \mathrm{g} \mathrm{mL}-1 \text { ), demonstrando que } \\
\text { não é necessária tanta concentração do } \\
\text { composto para obter a atividade antimicrobiana. } \\
\text { Das outras isoflavonas, a MIC ficou em } 100 \mu \mathrm{g} \\
\mathrm{mL}-1 \text {, não sendo eficaz contra as bactérias. }\end{array}$ & $\begin{array}{l}\text { Wang et al. } \\
\text { (2018) }\end{array}$ \\
\hline
\end{tabular}


REMPEL, C.; MACIEL, M. J.; BERGMANN, P. C.; MORÁS, A. P.; GOETTENS, C.

\begin{tabular}{|c|c|c|c|}
\hline Parte da planta & Tipo de estudo/Metodologia & Principais resultados & Referência \\
\hline Semente & $\begin{array}{l}\text { In vitro. Sementes foram desenvolvidas em ambiente } \\
\text { controlado até o estado de primeiro nó (V1). O inóculo } \\
\text { de } P \text {. sojae foi retirado de plantas contaminadas com o } \\
\text { patógeno e isolado em ágar V8. Plantas foram } \\
\text { infectadas por infestação por ferida do hipocótilo. } \\
\text { Mudas foram incubadas em câmara de nebulização } \\
\text { com todas condições ambientais controladas. Folhas } \\
\text { foram retiradas onde se extraiu o RNA e posterior } \\
\text { cDNA para obter o gene GmPR10 e analisar sua } \\
\text { capacidade antimicrobiana [adicionadas } 25 \mu g \text { de } \\
\text { GmPR10 em um canto da placa com o patógeno, } 15 \mu \mathrm{g} \\
\text { de recombinante GmPR10 renaturado em outro, } 15 \mu \mathrm{L} \\
\text { de tampão de eluição (controle) e } 25 \mu \mathrm{g} \text { de proteína de } \\
E \text {. coli em forma pET-29b] }\end{array}$ & $\begin{array}{l}\text { Foram detectadas zonas de inibição do patógeno } \\
\text { com a quantidade de } 25 \text { ug de proteína } \\
\text { recombinante GmPR10. Para o grupo controle e } \\
\text { da proteína de } E \text {. coli não houve sinal de inibição. }\end{array}$ & Xu et al. (2014) \\
\hline $\begin{array}{l}\text { Farelo de soja } \\
\text { desengordurado } \\
\text { (DSM) }\end{array}$ & $\begin{array}{c}\text { In vitro. Foi preparado um filme antimicrobiano com } \\
\text { DSM e lactoperoxidase (LPOS) por calor pressionando } \\
\text { uma mistura formadora de filme. O filme foi aplicado } \\
\text { em fatias de presunto e a Concentração Inibitória de } \\
\text { hipotiocianita (OSCN) foi determinada contra S. } \\
\text { Thyphimurium. }\end{array}$ & $\begin{array}{c}\text { DSM foi eficaz no transporte de OSCN, e } \\
\text { resultados sugeriram que o filme antimicrobiano } \\
\text { é promissor no controle de salmonelose } \\
\text { associado ao consumo de presunto. A } \\
\text { probabilidade de contaminação decresceu de } \\
44,7 \text { para } 9,0 \% \text {, enquanto o nível de redução de } \\
\text { Salmonella aumentou de } 2,0 \text { para } 2,6 \text { CFU/g de } \\
\text { um caso de salmonelose por ano. }\end{array}$ & $\begin{array}{l}\text { Lee et al. } \\
\text { (2015) }\end{array}$ \\
\hline $\begin{array}{c}\text { Cascas e farinha } \\
\text { de soja }\end{array}$ & $\begin{array}{l}\text { In vitro. Cascas e farinha de soja foram tratadas } \\
\text { previamente ao teste de pirólise, com diferentes } \\
\text { concentrações de H3PO4. Pirólise ocorreu de maneira } \\
\text { isotérmica a } 300^{\circ} \text { C por } 20 \text { minutos cada uso. } \\
\text { Compostos voláteis condensáveis foram obtidos } \\
\text { (orgânicos e aquosos) e separados. A molécula } \\
\text { Levoglucosenona foi detectada no bio-óleo adquirido } \\
\text { e sua atividade analisada contra os patógenos } S \text {. } \\
\text { Typhimurium selvagem, S. Typhimurium } \\
\text { phoPQ, E. coli, Serratia marcescens e } B \text {. subtilis. }\end{array}$ & $\begin{array}{l}\text { A molécula Levoglucosenona inibiu o crescimento } \\
\text { de todos patógenos testados. Contra as } \\
\text { Salmonella a molécula aumentou o tempo de fase } \\
\text { lag, atrasando-a. Acima de } \geq 160 \mu \mathrm{mL}-1 \mathrm{da} \\
\text { levoglucosenona a bactéria não recuperou seu } \\
\text { crescimento. Contra as outras bactérias, também } \\
\text { foi eficaz, com maior atividade vista em } E \text {. coli } \\
\text { seguida de B. subtilis. A Levoglucosenona é eficaz } \\
\text { tanto para bactérias Gram-positivas como Gram- } \\
\text { negativas. }\end{array}$ & $\begin{array}{l}\text { Giri et al. } \\
(2017)\end{array}$ \\
\hline Semente & $\begin{array}{l}\text { In vitro. Foi extraída a proteína tóxica da soja (SBTX) } \\
\text { para estudar seu efeito antimicrobiano contra o fungo } \\
\text { C. albicans. Foi visualizada a zona de inibição com o } \\
\text { tratamento do patógeno com a proteína em } \\
\text { concentrações de } 50 \text { a } 400 \mu \mathrm{g} / \mathrm{mL}-1 \text {. }\end{array}$ & $\begin{array}{l}\text { A SBTX foi eficaz na inibição do crescimento de } C \text {. } \\
\text { albicans na concentração entre } 50 \text { a } 400 \mu \mathrm{g} / \mathrm{mL}-1 \text {. } \\
\text { Na concentração de } 200 \mu \mathrm{g} / \mathrm{mL}-1 \text { mostrou } \\
\text { inibição em } 50 \% \text { do patógeno. Foi possível } \\
\text { analisar a forma de ação da SBTX, que } \\
\text { provavelmente atravessa a parede celular do } \\
\text { fungo e afeta o sensor de glicose Hgt4 presente } \\
\text { na membrana celular, bloqueando a absorção de } \\
\text { nutrientes de } C \text {. albicans, impedindo seu correto } \\
\text { desenvolvimento. }\end{array}$ & $\begin{array}{l}\text { Morais et al. } \\
\qquad(2013)\end{array}$ \\
\hline Semente & $\begin{array}{l}\text { In vitro. A SBTX foi extraída das sementes e testada } \\
\text { contra os fungos filamentosos Aspergillus niger, } P \text {. } \\
\text { herguei, F. oxysporum e } F \text {. solani analisando sua ação } \\
\text { na germinação dos esporos e crescimento do micélio } \\
\text { dos patógenos. Os fungos se desenvolveram em ágar } \\
\text { Sabourad por } 7 \text { dias a } 25^{\circ} \mathrm{C} \text {. O estudo foi conduzido em } \\
\text { pratos com a proteína e o conídio de cada fungo em } \\
\text { ambiente controlado, tendo como controle o fungo } \\
\text { sem SBTX. Após o tratamento, } 50 \text { conídios foram } \\
\text { selecionados para observação da germinação. } \\
\text { Considerou-se sucesso na germinação quando hifa } \\
\text { alcançasse o dobro do tamanho do conídio. Também } \\
\text { analisou o crescimento de fungos fermentadores (C. } \\
\text { albicans, C. parapsilosis, Kluyveromyces marxiannus e } \\
\text { Pichia membranifaciens), visualizando a zona de } \\
\text { inibição com o tratamento do patógeno com a } \\
\text { proteína em concentrações de } 50 \text { a } 400 \mu \text { g/mL-1. }\end{array}$ & $\begin{array}{l}\text { A proteína SBTX inibiu a germinação dos esporos } \\
\text { de } A \text {. niger e } P \text {. herguei em todas concentrações } \\
\text { testadas, porém, não surtiu efeito para } F \text {. } \\
\text { oxysporum e } F \text {. solani ao comparar com os } \\
\text { controles. Do crescimento do micélio, nenhum } \\
\text { dos fungos foi afetado pela proteína, mesmo à } \\
\text { concentração de } 500 \mu \mathrm{g} / \mathrm{mL} \text {. Dos fungos } \\
\text { fermentadores, a concentração de } 100 \mu \mathrm{g} / \mathrm{mL} \\
\text { inibiu } C \text {. albicans em } 54 \% \text { e } K \text {. marxiannus em } \\
48 \% \text { em } 42 \mathrm{~h} \text { de incubação. Em contrapartida, foi } \\
\text { ineficiente para } P \text {. membranifaciens e } C \text {. } \\
\text { parapsilosis, mesmo à concentração de } \\
400 \mu \mathrm{g} / \mathrm{mL} \text {. }\end{array}$ & $\begin{array}{l}\text { Morais et al. } \\
(2010)\end{array}$ \\
\hline Semente & $\begin{array}{l}\text { In vitro. O estudo comparou a capacidade } \\
\text { antimicrobiana de extratos de soja, chá-verde e chá- } \\
\text { preto, individuais e com a adição de leite, através do } \\
\text { método de difusão em ágar e ensaio de diluição de } \\
\text { caldo. Os patógenos alimentares do estudo são E. coli, } \\
\text { Cronobacter sakazakii, S. aureus e L. monocytogenes. }\end{array}$ & $\begin{array}{l}\text { Os resultados indicaram que os extratos puros } \\
\text { das plantas dependem da dose adicionada para } \\
\text { obter o efeito antimicrobiano. Os extratos dos } \\
\text { chás verde e preto apresentaram melhor efeito } \\
\text { contra bactérias Gram-positivas, enquanto o } \\
\text { extrato de soja exibiu efeito similar em todos } \\
\text { patógenos testados. Ao se adicionar o leite nos } \\
\text { chás, os fenóis totais decresceram, porém a } \\
\text { eficácia antimicrobiana foi adquirida. }\end{array}$ & $\begin{array}{l}\text { Zhao et al. } \\
\text { (2015) }\end{array}$ \\
\hline
\end{tabular}




\begin{tabular}{|c|c|c|c|}
\hline Parte da planta & Tipo de estudo/Metodologia & Principais resultados & Referência \\
\hline Semente & $\begin{array}{l}\text { In vitro. Avaliou-se a atividade antimicrobiana de } \\
\text { Vigna radiata, Phaseolus vulgaris, G. max, Lupinus } \\
\text { albus, L. angustifolius, L. luteus, A. hypogaea contra L. } \\
\text { monocytogenes e S. aureus. Para tal, os patógenos } \\
\text { foram inoculados junto ao extrato de cada planta em } \\
\text { uma placa de } 96 \text { poços, com controles positivos } \\
\text { (ampicilina e comicina em água p/ L. monocytogenes e } \\
\text { S. aureus, respectivamente), negativos (suspensão de } \\
\text { TSB de bactéria) e brancos (sem bactérias), verificando } \\
\text { também a MBC. Também, adicionaram-se fungos nas } \\
\text { sementes das plantas e verificou-se as diferenças (G é } \\
\text { só a semente e GF com a adição do fungo) }\end{array}$ & $\begin{array}{l}\text { Registrou-se efeito antimicrobiano de uma até } \\
\text { sete horas contra } L \text {. monocytogenes nos extratos } \\
\text { de } P \text {. vulgaris e } L \text {. luteus. nas maiores } \\
\text { concentrações testadas ( } 1,0 \mathrm{mg} / \mathrm{mL} \text { ), exceto para } \\
\text { A. hypogea. Entre as sementes G e GF, GF } \\
\text { demonstraram maiores níveis de inibição que G. } \\
\text { Em GF, o maior efeito ocorreu do extrato de } A \text {. } \\
\text { hypogea, seguido de } V \text {. radiata, G. max e } L \text {. } \\
\text { luteus. Para } S \text {. aureus, apenas o extrato de } A \text {. } \\
\text { hypogea apresentou atividade a } 0,5 \text { e } 1,0 \mathrm{mg} / \mathrm{mL} \text {. }\end{array}$ & $\begin{array}{l}\text { Lopes et al. } \\
\text { (2015) }\end{array}$ \\
\hline \multicolumn{4}{|c|}{ Mentha L. = Mentha piperita L. } \\
\hline Planta & $\begin{array}{l}\text { In vitro. Foi avaliado o potencial antimicrobiano dos } \\
\text { óleos essenciais de oito ervas (Thymus vulgaris, Allium } \\
\text { cepa, A. sativum, Eucalyptus globulus, Salvia } \\
\text { officinalis, Dianthus caryophyllus, M. spicata e M. } \\
\text { piperita) contra a bactéria E. coli pelo método de } \\
\text { difusão de disco. Também foi avaliada a MIC e MBC } \\
\text { por ensaio de microdiluição. }\end{array}$ & $\begin{array}{l}\text { Os resultados de MIC e MBC indicaram que } D \text {. } \\
\text { caryophyllus, } T \text {. vulgaris, } M \text {. spicata, } M \text {. piperita e } \\
E \text {. globulus possuem propriedades } \\
\text { bacteriostáticas e efeitos bactericidas. Dentre as } \\
\text { espécies, } E \text {. globulus, } T \text {. vulgaris e } D \text {. caryophyllus } \\
\text { demonstraram maiores níveis de inibição do } \\
\text { crescimento do patógeno, enquanto } A \text {. sativum, } \\
\text { A. cepa e } S \text {. officinalis não apresentaram } \\
\text { nenhuma zona de inibição. }\end{array}$ & $\begin{array}{c}\text { Golestani et al. } \\
\text { (2015) }\end{array}$ \\
\hline Planta & $\begin{array}{c}\text { In vitro. Foi avaliado o potencial antimicrobiano de } \\
\text { extratos de } 53 \text { plantas utilizadas na medicina } \\
\text { tradicional mexicana para desordens gastrointestinais, } \\
\text { verificando eficácia contra Heliobacter pylori. Os } \\
\text { métodos utilizados foram de diluição em ágar para } \\
\text { extrato aquoso e diluição em caldo para extrato } \\
\text { metanólico. }\end{array}$ & $\begin{array}{c}\text { Os extratos aquosos que apresentaram maiores } \\
\text { atividades antimicrobianas foram das plantas } \\
\text { Artemisia ludoviciana subsp. mexicana, Cuphea } \\
\text { aequipetala, Ludwigia repens e M. piperita, com } \\
\text { MIC de } 125 \text { a } 250 \mu \mathrm{g} / \mathrm{mL} \text {. Para os extratos } \\
\text { metanólicos foram as plantas Persea americana, } \\
\text { Annona cherimola, Guaiacum coulteri e } \\
\text { Moussonia deppeana, com MIC de 7,5 a } \\
15,6 \mu \mathrm{g} / \mathrm{mL} \text {. }\end{array}$ & $\begin{array}{c}\text { Castillo-Juárez } \\
\text { et al. (2009) }\end{array}$ \\
\hline $\begin{array}{l}\text { Partes aéreas da } \\
\text { planta }\end{array}$ & $\begin{array}{l}\text { In vitro. Foi preparado o extrato da planta e analisada } \\
\text { sua eficácia antimicrobiana contra S. aureus, S. } \\
\text { epidermidis, S. pyogenes resistente à penicilina, } E \text {. } \\
\text { faecalis, E. coli, K. pneumoniae, P. aeruginosa, Seratia } \\
\text { marcescens, A. baumannii e Stenotrophomonas } \\
\text { maltophilia. Os extratos de etanol, metanol, acetato } \\
\text { de etila e clorofórmio da planta foram feitos e } \\
\text { comparados os resultados de MIC e MBC. }\end{array}$ & $\begin{array}{l}\text { O extrato com acetato de etila foi o mais eficaz na } \\
\text { inibição do crescimento dos patógenos, seguido } \\
\text { do clorofórmio, etanol e metanol. A atividade } \\
\text { inibitória contra bactérias Gram-positivas foi } \\
\text { maior em acetato de etila que em clorofórmio, } \\
\text { metanol e etanol. O menor valor de MIC foi do } \\
\text { teste com a bactéria S. pyogenes, seguido de } S \text {. } \\
\text { epidermidis e. faecalis. Valores de MBC foram } \\
\text { maiores que de MIC em todos extratos para a } \\
\text { maioria dos patógenos. }\end{array}$ & $\begin{array}{c}\text { Shalayel et al. } \\
\qquad(2017)\end{array}$ \\
\hline Folhas & $\begin{array}{l}\text { In vitro. Extraiu-se o óleo essencial de quatro plantas } \\
\text { (M. piperita, Olea europaea, Prunus dulcis var. amara } \\
\text { e P. armeniaca) a partir de partes de cada uma e } \\
\text { obteve-se o óleo essencial comercial de } 26 \text { espécies } \\
\text { para avaliação da atividade antifúngica contra as } \\
\text { espécies Microsporum canis, Epidermophyton } \\
\text { floccosum, T. rubrum e T. mentagrophytes, além de } \\
\text { calcular valores de MIC. Foi feito o estudo aplicando } \\
\text { diferentes concentrações dos extratos nos patógenos } \\
\text { inoculados e misturando alguns óleos para testar seu } \\
\text { potencial. }\end{array}$ & $\begin{array}{l}\text { Os antidermatófitos mais eficazes foram dos } \\
\text { óleos essenciais de } P \text {. armeniaca, } P \text {. dulcis var. } \\
\text { amara, O. europaea e } M \text {. piperita comparando } \\
\text { com os comerciais das } 26 \text { plantas. Os valores de } \\
\text { MIC foram } 50,25 \text { e } 12,5 \mu \mathrm{g} / \text { disc para óleos puros, } \\
\text { combinação de dois óleos e combinação de } \\
\text { quatro óleos, respectivamente. }\end{array}$ & $\begin{array}{l}\text { Ibrahim et al. } \\
\qquad(2015)\end{array}$ \\
\hline Planta & $\begin{array}{c}\text { In vitro. Foram combinados os óleos essenciais } \\
\text { extraídos de } T \text {. vulgaris, S. officinalis, E. globulus e } M \text {. } \\
\text { piperita e avaliada a sua eficácia antimicrobiana contra } \\
\text { bactérias Gram-positivas ( } S \text {. aureus, E. coli e } P \text {. } \\
\text { aeruginosa), } 15 \text { isolados de bactérias marinhas Gram- } \\
\text { negativas (Pseudoalteromonas sp., Vibrio sp., } \\
\text { Shewanella sp., Agarivorans sp., Photobacterium sp.) e } \\
\text { bactérias marinhas incaracterizadas. O método para } \\
\text { tal foi o de ensaio de difusão e microdiluição para } \\
\text { definir MIC e MBC. }\end{array}$ & $\begin{array}{l}\text { Pelo ensaio de difusão a mistura dos óleos } \\
\text { essenciais apresentou zonas de apuramento ao } \\
\text { redor dos poços contendo os patógenos, } \\
\text { caracterizando a atividade antimicrobiana. No } \\
\text { controle negativo não houve a presença dessas } \\
\text { zonas, e na mistura-teste houve. Além disso, as } \\
\text { concentrações baixas da mistura já apresentaram } \\
\text { a atividade inibitória contra os patógenos. }\end{array}$ & $\begin{array}{c}\text { Mousavi et al. } \\
\text { (2011) }\end{array}$ \\
\hline Partes da planta & $\begin{array}{c}\text { In vitro. Extraiu-se o óleo essencial das plantas } \\
\text { Rosmarinus officinalis, Ocimum basilicum, } M \text {. } \\
\text { pulegium, } M \text {. spicata, Origanum dictamnus, } M \text {. } \\
\text { piperita, } O \text {. vulgare e Lavandula angustifolia, e } \\
\text { analisou-se a atividade antimicrobiana pelo método de } \\
\text { difusão de disco em ágar } \mathrm{MH} \text {, além de verificar valores } \\
\text { de MIC contra a bactéria } S \text {. aureus. }\end{array}$ & $\begin{array}{l}\text { Os óleos mais eficazes contra } S \text {. aureus foram } O \text {. } \\
\text { vulgare e } O \text {. dictamnus ao testar pelo método de } \\
\text { difusão de disco, mas ao avaliar MIC, os valores } \\
\text { foram bem altos, porém menores comparados } \\
\text { com os outros óleos. Uma cepa da bactéria foi } \\
\text { bem sensível à maioria dos óleos e resistente ao } \\
\text { óleo de } O \text {. basilicum. }\end{array}$ & $\begin{array}{l}\text { Alexopoulos et } \\
\text { al. (2011) }\end{array}$ \\
\hline
\end{tabular}


REMPEL, C.; MACIEL, M. J.; BERGMANN, P. C.; MORÁS, A. P.; GOETTENS, C.

\begin{tabular}{|c|c|c|c|}
\hline Parte da planta & Tipo de estudo/Metodologia & Principais resultados & Referência \\
\hline Folha & $\begin{array}{l}\text { In vitro. As folhas das plantas M. spicata, } M \text {. pulegium } \\
\text { e } M \text {. piperita foram secas e trituradas até se obter um } \\
\text { pó fino vegetal que foi utilizado para a produção dos } \\
\text { extratos. Eles foram utilizados para testar sua } \\
\text { atividade antimicrobiana contra bactérias Gram- } \\
\text { positivas e Gram-negativas pelo método de difusão } \\
\text { sólida e microdiluição. }\end{array}$ & $\begin{array}{l}\text { Bactérias Gram-positivas foram mais atingidas } \\
\text { que Gram-negativas. A bactéria mais sensível aos } \\
\text { extratos foi } S \text {. aureus. }\end{array}$ & $\begin{array}{l}\text { Barchan et al. } \\
\qquad(2016)\end{array}$ \\
\hline Folha & $\begin{array}{l}\text { In vitro. Obteve-se o extrato das folhas da planta e } \\
\text { testou-se a atividade antimicrobiana contra S. aureus, } \\
\text { S. pyogenes (Gram-positivas), E. coli e K. pneumonia } \\
\text { (Gram-negativas). Bactérias foram inoculadas, onde } \\
\text { realizou-se o método de difusão em ágar em } \\
\text { diferentes concentrações do extrato para verificar a } \\
\text { inibição dos patógenos. }\end{array}$ & $\begin{array}{l}\text { As zonas de inibição foram maiores nas bactérias } \\
\text { Gram-positivas que nas Gram-negativas testadas. } \\
\text { A bactéria mais sensível ao extrato foi } S \text {. aureus, } \\
\text { seguida de } S . \text { pyogenes e } K \text {. pneumoniae. A menor } \\
\text { zona de inibição foi para o teste com } E \text {. coli. O } \\
\text { menor valor de MIC foi para } K . \text { pneumoniae. }\end{array}$ & $\begin{array}{l}\text { Singh et al. } \\
\text { (2015) }\end{array}$ \\
\hline Óleo essencial & $\begin{array}{l}\text { In vitro. Foi avaliado o potencial antifúngico do óleo } \\
\text { essencial de onze plantas contra } L \text {. fungicola var. } \\
\text { fungicola e } A \text {. bisporus pelo método de macrodiluição. } \\
\text { O MIC também foi determinado para cada planta. }\end{array}$ & $\begin{array}{c}\text { A maior atividade antifúngica ocorreu com os } \\
\text { óleos essenciais das plantas Zatariam ultiflora, } \\
\text { Satureja hortensis, Pelargonium roseum e } M \text {. } \\
\text { piperita contra L. fungicola e A. bisporus. A menor } \\
\text { atividade antimicrobiana, contra ambos } \\
\text { patógenos, ocorreu nas plantas Citrus limonum, C. } \\
\text { aurantium e A. dracunculus. }\end{array}$ & $\begin{array}{l}\text { Mehrparvar et } \\
\text { al. (2016) }\end{array}$ \\
\hline Óleo essencial & $\begin{array}{l}\text { In vitro. Verificou-se o efeito antimicrobiano de } \\
\text { Cymbopogon citratus, } M \text {. arvensis, } M \text {. piperita e } E \text {. } \\
\text { globulus contra o patógeno } P \text {. fluorescens através do } \\
\text { método de ensaio de volatilização de disco, além de } \\
\text { determinar a MIC por diluição em ágar em várias } \\
\text { concentrações e tempo de morte, sendo esse último } \\
\text { analisado na fase de vapor do óleo essencial } \\
\text { juntamente com Íon de Ar Negativado (NAI). }\end{array}$ & $\begin{array}{l}\text { Em relação aos valores MIC, a atividade } \\
\text { antimicrobiana depende da concentração do óleo } \\
\text { essencial, tendo } C \text {. citratus e } M \text {. arvensis o menor } \\
\text { valor MIC e maior atividade antibacteriana } \\
\text { comparado com } M \text {. piperita e } E \text {. globulus. A maior } \\
\text { zona de inibição ocorreu em } C \text {. citratus. } E \text {. } \\
\text { globulus apresentou melhor inibição em sua } \\
\text { menor concentração ( } 20 \mu \text { l), seguido de } C \text {. citratus } \\
\text { e Mentha spp. Do tempo de morte ao patógeno, } \\
\text { o óleo essencial mais eficaz foi } C \text {. citratus, seguido } \\
\text { de } M \text {. arvensis, } M \text {. piperita e } E \text {. globulus. Em } \\
\text { relação à junção do óleo com NAI, a ordem de } \\
\text { eficiência é a mesma. }\end{array}$ & $\begin{array}{l}\text { Tyagi et al. } \\
\text { (2010) }\end{array}$ \\
\hline $\begin{array}{l}\text { Partes aéreas } \\
\text { secas da planta }\end{array}$ & $\begin{array}{l}\text { In vitro. Extraiu-se o óleo essencial de } T \text {. vulgaris, } O \text {. } \\
\text { vulgare, } R \text {. officinalis, Verbena officinalis, O. basilicum, } \\
\text { M. piperita, M. pulegium e M. spicata para analisar o } \\
\text { efeito antimicrobiano contra bactérias Gram-positivas } \\
\text { (L. monocytogenes, Clostridium perfringens, B. cereus, } \\
\text { S. aureus, E. faecium, E. faecalis e S. epidermidis) e } \\
\text { Gram-negativas (S. enterica, E. coli e } P \text {. aeruginosa) } \\
\text { pelo método de difusão de disco em ágar BHI e } \\
\text { determinou-se a MIC. }\end{array}$ & $\begin{array}{l}\text { S. aureus foi a bactéria mais atingida por todos } \\
\text { óleos essenciais, seguida de } E \text {. faecium e } E \text {. } \\
\text { faecalis. A bactéria mais resistente aos óleos } \\
\text { testados foi } P \text {. aeruginosa. As plantas mais } \\
\text { eficientes foram } T \text {. vulgaris, } O \text {. vulgare e } M \text {. } \\
\text { pulegium, sendo as duas primeiras de forte } \\
\text { inibição por surtirem efeito em quase todas } \\
\text { bactérias, menos } E \text {. faecalis. O efeito mais fraco } \\
\text { foi de } O \text {. basilicum e } M \text {. spicata. Nenhuma das } \\
\text { plantas inibiu L. monocytogenes. M. piperita } \\
\text { apresentou inibição moderada de } E \text {. coli e } S \text {. } \\
\text { epidermidis. }\end{array}$ & $\begin{array}{l}\text { Silva et al. } \\
\text { (2012) }\end{array}$ \\
\hline Óleo essencial & $\begin{array}{l}\text { In vitro. O óleo essencial de } M \text {. piperita foi extraído e } \\
\text { sua atividade antimicrobiana testada contra as } \\
\text { bactérias } E \text {. coli, } P \text {. aeruginosa, } P \text {. fluorescens, } B \text {. } \\
\text { subtilis e } S \text {. aureus, e fungos } P \text {. digitatum, } \text { A. flavus, } A \text {. } \\
\text { niger, Mucor spp., F. oxysporum, além dos } \\
\text { fermentadores } C \text {. albicans e Sacchromyce cerevisiae. O } \\
\text { método utilizado foi por diluição em ágar, difusão e } \\
\text { volatilização de disco. Foram determinados MIC, MBC } \\
\text { e Concentração Fungicida Mínima (MFC). }\end{array}$ & $\begin{array}{c}\text { A MIC e MFC da planta variou de } 1,13 \text { a } \\
2,25 \mathrm{mg} / \mathrm{ml} \text {, e MBC de } 2,25 \text { a } 9 \mathrm{mg} / \mathrm{ml} \text {. A zona de } \\
\text { inibição de bactérias variou de } 13 \text { a } 22 \mathrm{~mm} \text {, sendo } \\
\text { a menor zona de } P \text {. aeruginosa e maior de } B \text {. } \\
\text { subtilis. No teste em vapor, a zona foi maior, de } \\
22 \text { a } 35 \mathrm{~mm} \text {, sendo } P \text {. fluorescens a menor e } B \text {. } \\
\text { subtilis, novamente, a maior. Do tempo de morte } \\
\text { dos patógenos, em } 8 \text { horas de exposição } 100 \% \text { de } \\
\text { C. albicans e } B \text {. subtilis tiveram viabilidade } \\
\text { reduzida. }\end{array}$ & $\begin{array}{l}\text { Tyagi et al. } \\
\text { (2011) }\end{array}$ \\
\hline Óleo essencial & $\begin{array}{l}\text { In vitro. Analisou-se o efeito antifúngico das plantas } O \text {. } \\
\text { vulgare, L. angustifolia, E. globulus, S. officinalis, } T \text {. } \\
\text { vulgaris, Syzygnium armaticum e M. piperita contra o } \\
\text { patógeno A. flavus pelo método de microatmosfera. } \\
\text { Determinou-se a MFC pelo método de concentração } \\
\text { gradual dos óleos. }\end{array}$ & $\begin{array}{c}\text { Todos óleos essenciais das plantas apresentaram } \\
\text { atividade antifúngica contra o patógeno em } \\
\text { estudo, sendo a ordem de eficiência } O \text {. vulgare, } T \text {. } \\
\text { vulgaris, S. armaticum, L. angustifolia, M. } \\
\text { piperita, S. officinalis e E. globulus em } \\
\text { concentração pura (100\%), sendo as últimas três } \\
\text { de menor atividade antifúngica. Do MFC, } O \text {. } \\
\text { vulgare obteve a maior atividade antifúngica, com } \\
\text { o menor valor de MFC. }\end{array}$ & $\begin{array}{l}\text { Císarová et al. } \\
\qquad(2015)\end{array}$ \\
\hline
\end{tabular}




\begin{tabular}{|c|c|c|c|}
\hline Parte da planta & Tipo de estudo/Metodologia & Principais resultados & Referência \\
\hline Planta & $\begin{array}{l}\text { In vitro. Foram realizados extratos das plantas } \\
\text { Aspalathus linearis, Camellia sinensis, } R \text {. officinalis, } \\
\text { Cymbopogon citrates, Morus alba, Sasa borealis, } \\
\text { Nelumbo nucifera, M. piperita, Diospyros kaki e Ilex } \\
\text { paraguariensis para avaliar seu potencial } \\
\text { antimicrobiano contra os patógenos orais S. sobrinus e } \\
\text { S. mutans, e alimentares L. monocytogenes, Shigella } \\
\text { flexneri e S. enterica. O método utilizado foi de } \\
\text { microdiluição do caldo para determinar MIC das } \\
\text { plantas e posterior Concentração Letal Mínima (MLC). }\end{array}$ & $\begin{array}{l}\text { O extrato de } C \text {. sinensis obteve maior eficácia } \\
\text { antimicrobiana contra todos os cinco patógenos. } \\
\text { I. paraguariensis foi mais eficaz contra bactérias } \\
\text { Gram-positivas comparando com as outras } \\
\text { plantas. }\end{array}$ & $\begin{array}{l}\text { Oh et al. } \\
(2013)\end{array}$ \\
\hline Folha & $\begin{array}{l}\text { In vitro. Para a extração dos óleos essencias das } \\
\text { plantas } M \text {. piperita, } C \text {. citratus, } O \text {. majorana e } O \text {. } \\
\text { basilicum utilizou-se o método de hidrodestilação. Foi } \\
\text { testada a atividade antimicrobiana contra } E \text {. coli, } S \text {. } \\
\text { enterica, } L \text {. monocytogenes e } E \text {. sakazakii pelo método } \\
\text { de difusão em ágar, em meio de cultura TSA. }\end{array}$ & $\begin{array}{c}\text { M. piperita obteve maior atividade antibacteriana } \\
\text { contra } E \text {. coli, seguido de } S \text {. enteritidis e } E \text {. } \\
\text { sakazakii, sendo que para } L \text {. monocytogenes a } \\
\text { atividade foi baixa. } E \text {. coli foi a bactéria mais } \\
\text { sensível aos óleos testados. L. monocytogenes foi } \\
\text { o patógeno mais resistente a todos óleos } \\
\text { essenciais. }\end{array}$ & $\begin{array}{l}\text { Valeriano et al. } \\
\qquad(2012)\end{array}$ \\
\hline Semente & $\begin{array}{l}\text { In vitro. As plantas } R \text {. officinalis, } O \text {. vulgare, } S \text {. } \\
\text { officinalis, } M \text {. piperita, } \text { A. sativum, Foeniculum vulgare, } \\
\text { S. montana, } T \text {. vulgaris e Coriandrum sativum foram } \\
\text { cultivadas em condições controladas e das sementes } \\
\text { se extraiu os óleos essenciais para a análise } \\
\text { antimicrobiana contra } 13 \text { patógenos. Disso, } \\
\text { determinou-se a MIC. }\end{array}$ & $\begin{array}{c}\text { Os menores valores de MIC (melhores atividades } \\
\text { antimicrobianas) foram dos óleos de } T \text {. vulgaris, } S \text {. } \\
\text { montana, } O \text {. vulgare e C. sativum. Para F. vulgare, } \\
\text { os resultados não foram suficientes para inibir, de } \\
\text { forma recomendada, os patógenos. Para } R \text {. } \\
\text { officinalis, S. officinalis, } M \text {. piperita e } A \text {. sativum, a } \\
\text { atividade antimicrobiana é um pouco limitada, } \\
\text { porém, existe. }\end{array}$ & $\begin{array}{l}\text { Pellegrini et al. } \\
\qquad(2018)\end{array}$ \\
\hline Flores & $\begin{array}{l}\text { In vitro. Partes aéreas do início da floração da planta } \\
\text { foi hidrodestilada para se obter o óleo essencial e } \\
\text { realizar o teste antimicrobiano contra inúmeros } \\
\text { patógenos (bactérias e fungos) pelo método de } \\
\text { microdiluição de caldo. Também foi testada a } \\
\text { atividade do óleo da planta adicionando os } \\
\text { antibióticos vancomicina, anfotericina B e } \\
\text { gentamicina. }\end{array}$ & $\begin{array}{l}\text { No geral, a planta apresentou alta ação inibitória } \\
\text { contra as bactérias Gram-positivas, Gram- } \\
\text { negativas e os fungos. O patógeno mais sensível à } \\
\text { ação do óleo da planta foi } C \text {. albicans, já o mais } \\
\text { resistente foi } P \text {. aeruginosa. O óleo apresentou } \\
\text { atividades sinérgicas com os antibióticos. }\end{array}$ & $\begin{array}{l}\text { Mahboubi et } \\
\text { al. (2014) }\end{array}$ \\
\hline Partes aéreas & $\begin{array}{l}\text { In vitro. Obteve-se o óleo essencial por hidrodestilação } \\
\text { e assim se avaliou a atividade antimicrobiana contra } \\
\text { vários patógenos (bactérias e fungos) pelo método de } \\
\text { difusão de disco e microdiluição. }\end{array}$ & $\begin{array}{c}\text { No geral, M. piperita apresentou significativa } \\
\text { ação antibacteriana e antifúngica. Os patógenos } \\
\text { que apresentaram as maiores zonas de inibição } \\
\text { foram S. aureus, M. flavus, B. subtilis, S. } \\
\text { epidermidis e S. enteritidis. As menores zonas de } \\
\text { inibição ocorreram em P. syringae, X. campestris, } \\
\text { Proteus vulgaris, Citrobacter freundi e Bukholdria } \\
\text { cepacia. }\end{array}$ & $\begin{array}{l}\text { Reddy et al. } \\
\text { (2017) }\end{array}$ \\
\hline Partes aéreas & $\begin{array}{l}\text { In vitro. Obteve-se o óleo essencial por destilação a } \\
\text { vapor das plantas } S \text {. officinalis, } R \text {. officinalis, } T \text {. } \\
\text { vulgaris, } M \text {. spicata e } M \text {. piperita. Foi adquirido o óleo } \\
\text { essencial comercial de } O \text {. basilicum por ter fortes } \\
\text { indícios anteriores de ação antimicrobiana. Da parte } \\
\text { antimicrobiana, determinou-se o MBC pelo método de } \\
\text { diluição em ágar contra E. coli, } S \text {. enteritidis, } S \text {. } \\
\text { typhimurium, Lactobacillus acidophilus e } \\
\text { Bifidobacterium breve. }\end{array}$ & $\begin{array}{c}\text { Todas bactérias apresentaram vulnerabilidade em } \\
\text { relação aos óleos essenciais testados. } O \text {. vulgare e } \\
T . \text { vulgaris apresentaram ação inibitória com } \\
\text { MBCs menores que } 5 \mathrm{mg} / \mathrm{mL} \text { para todos } \\
\text { patógenos testados, incluindo microorganismos } \\
\text { benéficos. } O \text {. basilicum foi mais eficaz contra } \\
\text { bactérias patogênicas que benéficas. Bactérias } \\
\text { gram-negativas foram mais susceptíveis aos óleos } \\
\text { testados que as Gram-positivas. }\end{array}$ & $\begin{array}{l}\text { Roldán et al. } \\
\text { (2010) }\end{array}$ \\
\hline Óleo essencial & $\begin{array}{l}\text { In vitro e In vivo. Óleos essenciais de } M \text {. piperita foram } \\
\text { testados a fim de verificar a eficácia contra o patógeno } \\
\text { A. flavus. O óleo foi encapsulado em nanogel CS-CI } \\
\text { para manter as propriedades antes de ser testado. } \\
\text { Determinou-se o MIC para diferentes concentrações. } \\
\text { Também foi feito o estudo in vivo aplicando o nanogel } \\
\text { CS-Cl com o óleo em tomates. }\end{array}$ & $\begin{array}{c}\text { O extrato apresentou propriedades antifúngicas } \\
\text { consideráveis contra A. flavus. O encapsulamento } \\
\text { foi um ponto positivo para o melhor desempenho } \\
\text { do óleo essencial, já que ao testar com os óleos } \\
\text { livres o desempenho foi menor. Do teste in vivo, } \\
\text { os tomates com concentração de 1000ppm foram } \\
\text { preservados por um mês, enquanto a fruta com o } \\
\text { fungo e sem o antimicrobiano começou a decair a } \\
\text { partir do terceiro dia, mostrando a eficácia do } \\
\text { óleo essencial. }\end{array}$ & $\begin{array}{c}\text { Beyki et al. } \\
\text { (2014) }\end{array}$ \\
\hline \multicolumn{4}{|c|}{ Mikania glomerata Spreng. e M. laevigata Schultz Bip Ex. Baker } \\
\hline Partes secas & $\begin{array}{l}\text { In vitro. As partes secas da planta foram pulverizadas e } \\
\text { maceradas com metanol por cinco dias à temperatura } \\
\text { ambiente. Após evaporação do solvente sob pressão } \\
\text { reduzida, os respectivos dias à temperatura ambiente. } \\
\text { Após evaporação do solvente sob pressão reduzida, } \\
\text { extratos nol foram obtidos, sendo mantidos em } \\
\text { frascos hermeticamente fechados, sob refrigeração } \\
\left(4^{\circ} \mathrm{C}\right) \text { até usado para testes biológicos e fitoquímicos. }\end{array}$ & $\begin{array}{c}\text { Extratos de Baccharis dracunculifolia, Cajanus } \\
\text { cajan, Eugenia uniflora, Solanum palinacanthum e } \\
\text { S. concinnum apresentaram forte atividade } \\
\text { antibacteriana com valores de MIC abaixo de } \\
10 \mu \mathrm{g} / \mathrm{mL} \text { para algumas estirpes. Os extratos de } \\
\text { M. glomerata e Leonurus sibiricus mostraram } \\
\text { toxicidade significativa contra salmoura camarão } \\
\text { com valores de CL50 de } 63 \text { e } 86 \mu \mathrm{g} / \mathrm{mL}, \\
\text { respectivamente. }\end{array}$ & $\begin{array}{l}\text { Bouzada et al. } \\
\text { (2009) }\end{array}$ \\
\hline
\end{tabular}




\begin{tabular}{|c|c|c|c|}
\hline Parte da planta & Tipo de estudo/Metodologia & Principais resultados & Referência \\
\hline $\begin{array}{l}\text { Os fungos foram } \\
\text { extraídos de folhas }\end{array}$ & $\begin{array}{l}\text { In vitro. Quarenta fungos endofíticos foram isolados } \\
\text { das folhas de } M \text {. glomerata coletadas no UEM-Jardim } \\
\text { Educativo ( } 23^{\circ} 24^{\prime} 14^{\prime \prime S}, 51^{\circ} 56^{\prime} 19^{\prime \prime} \text { W) em março de } \\
2013 \text { usando a fragmentação. }\end{array}$ & $\begin{array}{l}\text { O extrato bruto do secundário metabólitos da } \\
\text { cepa G-01 foi testada contra E. coli e S. aureus; os } \\
\text { metabólitos mostraram atividade antimicrobiana } \\
\text { contra S. aureus. Os endófitos testados neste } \\
\text { estudo têm potencial para utilização em } \\
\text { aplicações biotecnológicas. }\end{array}$ & $\begin{array}{l}\text { Polonio et al. } \\
\qquad(2015)\end{array}$ \\
\hline $\begin{array}{l}\text { Tinturas } \\
\text { hidroalcoólicas, } \\
\text { feitas a partir da } \\
\text { planta }\end{array}$ & $\begin{array}{l}\text { In vitro. A MIC foi determinada pela técnica da } \\
\text { microdiluição; como controle positivo foi utilizado a } \\
\text { Clorexidina } 0,12 \% \text {. A leitura foi feita após } 24 \text { horas, } \\
\text { pelo método visual. Os ensaios foram realizados em } \\
\text { triplicata. A MBC foi obtida pela semeadura da última } \\
\text { concentração bacteriostática e da sua anterior, para } \\
\text { cada produto, em meio ágar sangue. }\end{array}$ & $\begin{array}{c}\text { Sobre } S \text {. mutans, verificou-se } \mathrm{MIC} \text { de } 6,25 \mathrm{mg} / \mathrm{mL} \\
\text { para } \mathrm{T} 1, \mathrm{~T} 2 \text { e } \mathrm{T} 3 \text {, e MBC de } 12,5 \mathrm{mg} / \mathrm{mL} \text { para } \mathrm{T} 1 \mathrm{e} \\
\mathrm{T} 2 \text {, e de } 6,25 \mathrm{mg} / \mathrm{mL} \text { para T3. Sobre } S \text {. oralis todos } \\
\text { os produtos apresentaram MIC e MBC de } \\
0,78 \mathrm{mg} / \mathrm{mL} \text {. Para clorexidina, a MIC e MBC foram } \\
0,04 \mathrm{mg} / \mathrm{mL} \text { sobre } S \text {. mutans e } S \text {. oralis. }\end{array}$ & $\begin{array}{c}\text { Pinheiro et al. } \\
\text { (2012) }\end{array}$ \\
\hline $\begin{array}{c}\text { Partes secas da } \\
\text { planta }\end{array}$ & $\begin{array}{l}\text { In vitro e In vivo. Foram preparadas soluções com as } \\
\text { partes da planta com o etanol, por meio de } \\
\text { percolação. Os extratos foram concentrados em } \\
\text { evaporador rotativo a } 50^{\circ} \mathrm{C} \text { sob pressão reduzida, ao } \\
\text { resíduo, proporcionando respectivamente } 55 \mathrm{~g} \text { de } \\
\text { extrato etanólico de } M \text {. glomerata e } 35 \mathrm{~g} \text { de } M \text {. } \\
\text { laevigata. Após, foram realizadas as análises. }\end{array}$ & $\begin{array}{l}\text { O tratamento com clorexidina e } M . \text { glomerata foi } \\
\text { estatisticamente semelhante }(p>0,05) \text {. O } \\
\text { enxaguatório bucal de } M \text {. glomerata pode ser útil } \\
\text { em programas de estratégia fitoterápica contra } S \text {. } \\
\text { mutans e o marcador cumarina pode não estar } \\
\text { relacionado com a atividade observada. }\end{array}$ & $\begin{array}{l}\text { Lessa et al. } \\
\qquad(2012)\end{array}$ \\
\hline $\begin{array}{c}\text { Partes aéreas } \\
\text { secas }\end{array}$ & $\begin{array}{l}\text { In vitro. Foi preparado um extrato juntamente com } \\
\text { metanol, e filtrado. Após foi avaliado como } \\
\text { ingrediente herbal para ser usado em produtos de } \\
\text { higiene bucal, sendo testado em diversos tipos de } \\
\text { bactérias que podem causar cárie. }\end{array}$ & $\begin{array}{l}\text { Considerando a ausência de atividade genotóxica } \\
\text { e citotóxica sob as condições testadas, sugere-se } \\
\text { que o KAMg (extrato) seja um produto natural a } \\
\text { ser considerado como ingrediente ativo no } \\
\text { cuidado bucal. }\end{array}$ & $\begin{array}{c}\text { Moreira et al. } \\
\text { (2016) }\end{array}$ \\
\hline $\begin{array}{c}\text { Partes aéreas } \\
\text { secas }\end{array}$ & $\begin{array}{l}\text { In vitro. Foi utilizado um extrato da planta, extraído } \\
\text { com diclorometano, concentrado e suspenso em } \\
\text { metanol, filtrado, onde a fração restante foi } \\
\text { cromatografada com n-hexano e depois com } 20 \% \text { de } \\
\text { acetato de etilo (n-hexano /etilo acetato 8: } 2 \text { ). A fração } \\
\text { n-hexana foi descartada e o n-hexano/acetato de etila } \\
\text { 8: } 2 \text { foi denominado MGE (extrato de M. glomerata). } \\
\text { Após, o extrato foi utilizado para avaliar o potencial de } \\
\text { um extrato rico em kaurenoic (KA) de } M \text {. glomerata } \\
\text { (isto é, MGE) e seu principal composto contra } \\
\text { bactérias que podem causar infecções endodônticas. }\end{array}$ & $\begin{array}{c}\text { Foi concluído que o extrato de } M \text {. glomerata e } \\
\text { seu principal composto ácido ent-caurenóico (KA) } \\
\text { apresentaram atividade antibacteriana in vitro, } \\
\text { sendo este último um potencial agente inibidor } \\
\text { do biofilme. }\end{array}$ & $\begin{array}{l}\text { Moreti et al. } \\
\text { (2017) }\end{array}$ \\
\hline \multicolumn{4}{|l|}{ Salix alba L. } \\
\hline $\begin{array}{l}\text { Partes secas da } \\
\text { planta }\end{array}$ & $\begin{array}{l}\text { In vitro e In vivo. Dez espécies de plantas encontradas } \\
\text { no Irã foram selecionadas e coletadas com base } \\
\text { literatura disponível sobre a medicina tradicional } \\
\text { iraniana. Os extratos metanólicos destas plantas foram } \\
\text { investigados quanto às propriedades antimaláricas in } \\
\text { vitro contra as sensíveis a cloroquina (3D7) e cepas } \\
\text { resistentes a drogas (K1) de Plasmodium falciparum. } \\
\text { Sua atividade in vivo contra a infecção por P. berghei } \\
\text { em camundongos também foi determinada. Testes de } \\
\text { citotoxicidade foram realizados usando a linha de } \\
\text { células Raji o ensaio MTT. Os extratos foram } \\
\text { rastreados fitoquimicamente por seus constituintes } \\
\text { ativos. }\end{array}$ & $\begin{array}{l}\text { De acordo com os valores de IC50 e índice de } \\
\text { seletividade (SI) das } 10 \text { espécies de plantas } \\
\text { selecionadas, Citrullus colocynthis, Physalis } \\
\text { alkekengi e S. nigrum apresentaram atividade } \\
\text { antimalárica in vitro potente contra cepas 3D7 e } \\
\text { K1 sem toxicidade. Comparações entre controles } \\
\text { de camundongos tratados e não tratados } \\
\text { mostraram que as espécies de plantas } \\
\text { mencionadas reduziram a parasitemia em } \\
65,08 \%, 57,97 \% \text { e } 60,68 \% \text {, respectivamente. A } \\
\text { existência de compostos antiplasmodiais foi } \\
\text { detectada nesses extratos vegetais. }\end{array}$ & $\begin{array}{l}\text { Haddad et al. } \\
\qquad(2017)\end{array}$ \\
\hline Folhas & $\begin{array}{l}\text { As folhas foram limpas com água destilada, secas à } \\
\text { sombra e transformadas em pó. O material em pó } \\
(10 \mathrm{~g}) \text { foi colocado num frasco contendo } 100 \mathrm{ml} \mathrm{de} \\
\text { água destilada aquecida e agitado durante } 20 \mathrm{~min} \\
\text { numa placa quente. O extrato foi filtrado sob vácuo e } \\
\text { resfriado imediatamente em gelo. A sua estabilidade } \\
\text { foi avaliada contra volumes variáveis de pH e cloreto } \\
\text { de sódio, bem como a temperatura elevada, } \\
\text { juntamente com inibição de enzimas, atividade } \\
\text { antibacteriana, antifúngica, antinociceptiva, relaxante } \\
\text { muscular e sedativa. }\end{array}$ & $\begin{array}{l}\text { A boa atividade antifúngica com atenuação } \\
\text { significativa da dor, bem como efeito relaxante } \\
\text { muscular de nanopartículas de ouro pode ser } \\
\text { potencialmente aplicado em vários produtos, tais } \\
\text { como preparações tópicas. O processo de síntese } \\
\text { de nanopartículas em larga escala, utilizando o } \\
\text { extrato de folhas de } S \text {. alba, pode ter várias } \\
\text { vantagens, como custo-efetividade e } \\
\text { compatibilidade para aplicações biomédicas e } \\
\text { farmacêuticas. }\end{array}$ & $\begin{array}{l}\text { Islam et al. } \\
\text { (2015) }\end{array}$ \\
\hline
\end{tabular}




\begin{tabular}{|c|c|c|c|}
\hline Parte da planta & Tipo de estudo/Metodologia & Principais resultados & Referência \\
\hline Folhas & $\begin{array}{l}\text { In vitro. O material foi coletado em todos os meses no } \\
\text { período de } 2012 \text { a } 2013 \text { e, para a pesquisa, foram } \\
\text { utilizadas apenas folhas sem sinais de clorose. Durante } \\
\text { a amostragem, medições meteorológicas e } \\
\text { observações fenológicas foram realizadas. A atividade } \\
\text { microbiana foi determinada pelo método de } \\
\text { "inundação" das culturas com teste de bactérias } \\
\text { Gram-positivas ( } B \text {. subtilis e } E \text {. coli) e Gram-negativas. } \\
\text { Folhas inteiras foram colocadas na tampa, que foi } \\
\text { coberta com uma placa de Petri com culturas, } \\
\text { excluindo o contato com as folhas, sendo que as } \\
\text { placas foram mantidas por } 4 \text { h à luz do dia e } \\
\text { temperatura ambiente. No outro dia foram colocadas } \\
\text { no termostato a } 37 \text { o e contadas as colônias de } \\
\text { bactérias, determinando o grau de inibição da cultura } \\
\text { de teste em relação ao controle. }\end{array}$ & $\begin{array}{l}\text { A pesquisa comprova que a atividade } \\
\text { antimicrobiana dos compostos orgânicos voláteis } \\
\text { das folhas das espécies em estudo é sensível ao } \\
\text { impacto dos poluentes. Além disso, a atividade } \\
\text { antimicrobiana de folhas de Betula pendula, S. } \\
\text { alba, Fraxinus excelsior, Robinia pseudoacacia, } \\
\text { Populus nigra aumenta sob a influência de } \\
\text { poluentes de usinas metalúrgicas e de } \\
\text { escapamentos de tráfego. A capacidade } \\
\text { antimicrobiana de Aesculus hippocastanum, Tilia } \\
\text { cordata e Picea pungens aumenta nas áreas com } \\
\text { o ar mais limpo. }\end{array}$ & $\begin{array}{l}\text { Volodarez } \\
\text { (2015) }\end{array}$ \\
\hline \multicolumn{4}{|c|}{ Schinus terebinthifolius Raddi. } \\
\hline Frutos e folhas & $\begin{array}{l}\text { A composição química dos três OEs extraídos de } S \text {. } \\
\text { terebinthifolius e } S \text {. molle foram estudadas a fim de } \\
\text { avaliar sua eficiência antimicrobiana e antifúngica in } \\
\text { vitro. Para a extração dos óleos, folhas e frutos secas } \\
\text { (ao ar) foram colocados em um balão de destilação de } \\
\text { fundo redondo de } 5 \mathrm{~L} \text { e adicionou } 3 \mathrm{~L} \text { de água destilada. } \\
\text { Os óleos foram obtidos por destilação a vapor por } 3 \mathrm{~h} \\
\text { usando um aparelho do tipo Clevenger. Depois de } \\
\text { remover traços de água com sulfato de sódio anidro, } \\
\text { os EOs foram armazenados em um frasco de vidro } \\
\text { âmbar limpo até ser usado. }\end{array}$ & $\begin{array}{l}\text { Os microrganismos testados exibiram diferentes } \\
\text { níveis de sensibilidade para cada óleo testado. } \\
\text { Todos os OEs investigados reduziram o } \\
\text { crescimento micelial dos fungos quando usados } \\
\text { concentrações de } 250 \text { a } 1000 \text { ppm e de } 2000 \text { a } \\
\text { 8000ppm contra Colletotrichum acutatum e } B \text {. } \\
\text { cinerea, respectivamente. Superior as } \\
\text { concentrações dos mesmos óleos exibiram um } \\
\text { efeito fungicida contra ambos os fungos } \\
\text { mitospóricos. O óleo extraído de folhas de } S \text {. } \\
\text { terebinthifolius inibiu significativamente o } \\
\text { crescimento de cepas bacterianas testadas. }\end{array}$ & $\begin{array}{c}\text { Elshafie et al. } \\
\qquad(2016)\end{array}$ \\
\hline $\begin{array}{l}\text { Folhas, caule, } \\
\text { casca e fruta }\end{array}$ & $\begin{array}{l}\text { In vitro. Materiais vegetais foram extraídos por } \\
\text { maceração com etanol } 80 \% \text { durante } 10 \text { dias à } \\
\text { temperatura ambiente. Após a filtração, o extrato } \\
\text { hidroalcoólico (EtOH) foi concentrado sob pressão } \\
\text { reduzida para fornecer extratos brutos, cujos foram } \\
\text { suspensos em água destilada e extraídos } \\
\text { sucessivamente com hexano (HEX), diclorometano } \\
\text { (DCM) e acetato de etila (AcOEt). Após a separação } \\
\text { das fases, os solventes foram removidos num } \\
\text { evaporador rotativo a } 45^{\circ} \mathrm{C} \text { sob vácuo. Todos os } \\
\text { extratos e frações foram submetidos aos ensaios } \\
\text { biológicos. }\end{array}$ & $\begin{array}{l}\text { As três linhagens de P. brasiliensis apresentaram } \\
\text { perfis de suscetibilidade semelhantes em relação } \\
\text { aos extratos vegetais testados. As frações } \\
\text { hexânicas dos extratos de } \text { S. terebinthifolius, } \\
\text { Rubus urticaefolia, } B \text {. dracunculifolia, Piper } \\
\text { abutiloides, } P \text {. regnellii e Herissantia crispa foram } \\
\text { mais ativas contra o fungo quando comparadas } \\
\text { com as demais frações dessas plantas. Todos os } \\
\text { isolados de } P \text {. brasiliensis testados foram } \\
\text { resistentes ao extrato etanólico de } \text { Alternanthera } \\
\text { brasiliana na concentração de } 1000 \mu \mathrm{g} / \mathrm{mL} \text {. }\end{array}$ & $\begin{array}{l}\text { Johann et al. } \\
\qquad(2010)\end{array}$ \\
\hline Folhas secas & $\begin{array}{l}\text { In vitro. Folhas secas (400g) foram extraídas por } \\
\text { maceração em quatro litros de etanol a } 80 \% \text { durante } \\
\text { dez dias. Após a eliminação do solvente, } 36 \mathrm{~g} \text { de um } \\
\text { extrato hidroalcoólico (HA-L) foi obtido, cujo foi então } \\
\text { particionado entre água e, sucessivamente, com } \\
\text { hexano, diclorometano e acetato de etila, resultando } \\
\text { em } 1,4 \mathrm{~g} \text { de uma fração hexânica (HEX-L), } 5 \mathrm{~g} \text { de uma } \\
\text { fração diclorometano (DCM-L) e } 6,6 \mathrm{~g} \text { da fração acetato } \\
\text { de etila (EA-L) e } 15,2 \mathrm{~g} \text { da fração aquosa (AQ-L). } \\
\text { Determinou-se MIC e MFC contra P. brasiliensis, com } \\
\text { anfotericina B e trimetropina de controle positivo de } \\
\text { MIC. }\end{array}$ & $\begin{array}{l}\text { Foram identificados dois compostos nas folhas de } \\
\text { S. terebinthifolius cujos possuem atividades } \\
\text { eficientes contra linhagens de } P \text {. brasiliensis. Um } \\
\text { dos compostos apresentou efeito sinérgico } \\
\text { apenas quando combinado com itraconazol. Os } \\
\text { compostos isolados de } S \text {. terebinthifolius não } \\
\text { foram capazes de inibir a síntese ou a formação } \\
\text { da parede celular utilizando o ensaio de sorbitol. }\end{array}$ & $\begin{array}{l}\text { Johann et al. } \\
\qquad(2010)\end{array}$ \\
\hline $\begin{array}{l}\text { Partes diversas das } \\
\text { plantas }\end{array}$ & $\begin{array}{l}\text { In vitro. Nove espécies de plantas de vegetação } \\
\text { semiárida foram selecionadas para esse estudo. Partes } \\
\text { das plantas foram secas a } 45^{\circ} \mathrm{C} \text { e reduzidas a pó com o } \\
\text { triturador Willey mill ( }\left(\mathrm{d} d a m 0^{\circledR} \text { ) e as soluções do }\right. \\
\text { extrato foram obtidas por refluxo utilizando água } \\
\text { (extrato aquoso, AE), etanol: água ( } 1: 1, \mathrm{v} / \mathrm{v} \text {, extrato } \\
\text { etanólico, EE), ou acetona: água ( } 1: 1, \mathrm{v} / \mathrm{v} \text {, extrato de } \\
\text { acetona, AcE). Após, foi analisada a ação antifúngica } \\
\text { dos extratos. }\end{array}$ & $\begin{array}{c}\text { Todas as plantas de caatinga estudadas } \\
\text { apresentaram efeito fungicida contra o complexo } \\
\text { T. rubrum e } T \text {. mentagrophytes. Excetuando } E \text {. } \\
\text { uniflora, Libidibia ferrea, } M \text {. tenuiflora e } P \text {. } \\
\text { guajava, foi descrita a atividade antifúngica de } S \text {. } \\
\text { terebinthifolius, Piptadenia colubrina, } \\
\text { Parapiptadenia rigida, Mimosa ophthalmocentra } \\
\text { e } P \text {. americana contra ambas as espécies de } \\
\text { fungos. }\end{array}$ & $\begin{array}{c}\text { Biasi-Garbin et } \\
\text { al. (2016) }\end{array}$ \\
\hline
\end{tabular}




\begin{tabular}{|c|c|c|c|}
\hline Parte da planta & Tipo de estudo/Metodologia & Principais resultados & Referência \\
\hline $\begin{array}{l}\text { Grãos e frutos sem } \\
\text { pedúnculo }\end{array}$ & $\begin{array}{l}\text { In vitro. As pimentas utilizadas foram higienizadas e } \\
\text { secas antes da extração do óleo. Os OEs foram } \\
\text { extraídos pelo método hidrodestilação, usando } \\
\text { aparelho Clevenger; após destilação, foi realizada uma } \\
\text { partida com diclorometano ( } 3 \times 30 \mathrm{~mL} \text { ) para separar o } \\
\text { óleo da água, após, o óleo foi concentrado em um } \\
\text { evaporador rotativo para eliminar o diclorometano. } \\
\text { Também foi utilizado o método de extração de } \\
\text { Soxhlet, onde a amostra foi adicionada a um cartucho } \\
\text { que foi coberto com algodão. Esse cartucho foi } \\
\text { colocado em um extrator Soxhlet, que foi incorporado } \\
\text { em um frasco de } 500 \text { mL contendo acetona, que foi } \\
\text { anexado a uma manta de aquecimento. Após o } \\
\text { período de extração, o solvente foi evaporado em } \\
\text { evaporador rotativo (TECNAL, TE-210) e o óleo foi } \\
\text { obtido. }\end{array}$ & $\begin{array}{l}\text { Os resultados obtidos mostram que dois OEs } \\
\text { (Pimenta dioica e } S \text {. terebinthifolius) e três } \\
\text { oleoresinas (S. terebinthifolius e } P \text {. nigrum branco } \\
\text { e preto) apresentaram atividade antimicrobiana } \\
\text { significativa. Esses OEs e oleoresinas bioativos } \\
\text { mostram-se interessantes para a utilização em } \\
\text { processos biotecnológicos empregados na } \\
\text { indústria alimentar, farmacêutica e outras } \\
\text { indústrias. }\end{array}$ & $\begin{array}{l}\text { Martinelli et } \\
\text { al. (2017) }\end{array}$ \\
\hline $\begin{array}{c}\text { Partes secas das } \\
\text { plantas }\end{array}$ & $\begin{array}{l}\text { In vitro. Após a secagem em estufa a } 40^{\circ} \mathrm{C} \text {, os } \\
\text { farmacogênicos foram moídos para obter um pó fino. } \\
\text { Para preparar os extratos, } 10 \mathrm{~g} \text { de pó de cada planta } \\
\text { foram fervidos em } 100 \mathrm{~mL} \text { de água destilada por } 10 \mathrm{~min} \\
\text { para obter uma forma etnofarmacológica específica. A } \\
\text { solução hidroalcoólica a } 50 \% \text { foi utilizada porque os } \\
\text { extratos são preparados com cachaça brasileira em } \\
\text { culturas populares que contém uma concentração } \\
\text { alcoólica próxima. Após a preparação dos extratos } \\
\text { foram filtrados através de papel de filtro sob pressão } \\
\text { reduzida, e evaporados sob vácuo e liofilizados. }\end{array}$ & $\begin{array}{l}\text { Dos extratos testados, nenhuma planta mostrou } \\
\text { índice de seletividade (SI) } 41 \text { para as bactérias } \\
\text { testadas; Campomanesia eugenioides e } S \text {. } \\
\text { terebinthifolius tiveram um SI } 41.0 \text { para todas as } \\
\text { espécies de Candida testadas. A melhor atividade } \\
\text { anti-Leishmania foi obtida com Zanthoxylum } \\
\text { rhoifolium e S. terebinthifolius. Os extratos de } \\
\text { Cordia americana foram os mais efetivos contra o } \\
\text { vírus herpes simplex tipo } 1 . \text { O extrato de } Z \text {. } \\
\text { rhoifolium foi o mais efetivo contra o Poliovírus, e } \\
\text { o Ocimum gratissimum foi efetivo contra o vírus } \\
\text { Poliovírus e Herpes Simplex. Entre as plantas } \\
\text { investigadas no presente estudo, Z. rhoifolium } \\
\text { teve o menor efeito citotóxico. }\end{array}$ & $\begin{array}{l}\text { Moura-Costa } \\
\text { et al. (2012) }\end{array}$ \\
\hline Frutos & $\begin{array}{l}\text { In vitro. O OE foi extraído por hidrodestilação } \\
\text { utilizando aparelho Clevenger. O OE resultante foi } \\
\text { desidratado por centrifugação a } 6600 \mathrm{~g} \text { por } 60 \\
\text { segundos em uma centrífuga refrigerada (Eppendorf } \\
\mathrm{F}^{\circledR} \text { Centrifuge } 6430 \mathrm{R} \text { ) e subsequentemente filtrado } \\
\text { com sulfato de sódio anidro ( } \mathrm{Na} 2 \mathrm{SO} 4 \text { - } \mathrm{SYNTH}^{\circledR} \text { ); após, } \\
\text { o óleo foi armazenado em um frasco de vidro âmbar e } \\
\text { mantido a }-80^{\circ} \mathrm{C} \text { até a análise. As bactérias utilizadas } \\
\text { na análise foram selecionadas baseando-se em sua } \\
\text { importância acerca de alimentos e também as } \\
\text { aplicáveis na tecnologia, sendo elas em } 18 \text { espécies. }\end{array}$ & $\begin{array}{l}\text { O OE de } S \text {. terebinthifolius apresentou uma ótima } \\
\text { atividade antimicrobiana, com } \mathrm{MBC} \text { de } 6,8 \mathrm{mg} / \mathrm{mL} \\
\text { contra L. monocytogenes, além de reduzir seu } \\
\text { desenvolvimento em } 1,3 \mathrm{log} \text { CFU/g em } 30 \text { dias. } \\
\text { Isso significa que tem grande potencial para ser } \\
\text { utilizado na preservação de alimentos. }\end{array}$ & $\begin{array}{c}\text { Dannenberg et } \\
\text { al. (2016) }\end{array}$ \\
\hline Folhas & $\begin{array}{l}\text { In vitro. Foram trituradas folhas secas de } S \text {. } \\
\text { terebinthifolius até obter pó e, após, } 20 \text { g desse foi } \\
\text { suspenso em } 200 \mathrm{~mL} \text { de } \mathrm{NaCl} \text {. Após agitação durante } \\
16 \mathrm{~h} \text { a } 4^{\circ} \mathrm{C} \text {, a amostra foi filtrada através de gaze e } \\
\text { centrifugada a } 3000 \mathrm{~g} \text { durante } 15 \mathrm{~min} \text {. O sobrenadante } \\
\text { (extrato bruto) foi passado através de carvão ativado e } \\
\text { o filtrado (extrato de folhas) foi coletado. Após, esse } \\
\text { extrato foi utilizado para as análises MIC, MBC e MFC. }\end{array}$ & $\begin{array}{c}\text { Atividade antimicrobiana foi ativa contra } E \text {. coli, } K \text {. } \\
\text { pneumoniae, } P \text {. mirabilis, } P \text {. aeruginosa, } S . \\
\text { enteritidis e } S \text {. aureus. Maiores efeitos } \\
\text { bacteriostáticos e bactericidas foram detectados } \\
\text { para } S . \text { enteritidis e } S \text {. aureus, respectivamente. } S \text {. } \\
\text { terebinthifolius prejudicou o crescimento e } \\
\text { sobrevivência de } C \text {. albicans. }\end{array}$ & $\begin{array}{c}\text { Gomes et al. } \\
(2012)\end{array}$ \\
\hline Caule e casca & $\begin{array}{l}\text { In vitro. O extrato foi obtido por meio do processo de } \\
\text { decocção, esgotando-se a planta fragmentada em } \\
\text { água destilada, na proporção } 1 \mathrm{~g} \text { : } 10 \mathrm{~mL} \text {, e levando à } \\
\text { ebulição em fogo brando por } 15 \text { minutos, utilizando-se } \\
20 \mathrm{~g} \text { do produto para } 200 \mathrm{~mL} \text { de água destilada. O } \\
\text { ensaio para determinação da atividade antifúngica foi } \\
\text { realizado pelo método da difusão em meio sólido. Em } \\
\text { placas de Petri estéreis foram adicionados } 20 \mathrm{~mL} \text { de } \\
\text { ágar Sabouraud Dextrose (ASD) fundido e resfriado a } \\
45-50^{\circ} \mathrm{C} \text {. Após solidificação do ágar, foi inoculado } 1 \mathrm{~mL} \\
\text { da suspensão fúngica na concentração de } 106 \mathrm{UFC} \mathrm{mL}- \\
\text { 1. Em seguida, discos de papel de filtro estéreis foram } \\
\text { embebidos em } 50 \mu \mathrm{L} \text { dos decoctos e colocados sobre o } \\
\text { meio de cultura. Os resultados foram avaliados a partir } \\
\text { da mensuração dos diâmetros dos halos de inibição de } \\
\text { crescimento fúngico em milímetros (mm). }\end{array}$ & $\begin{array}{l}\text { Notaram-se diferenças nos resultados dos } \\
\text { produtos dependendo do lugar no qual haviam } \\
\text { sido comprados, mas apesar disso, todas as } \\
\text { espécies de plantas analisadas demonstraram } \\
\text { atividades antifúngicas nas cepas ensaiadas. } \\
\text { Destaca-se que o decoto de } P \text {. granatum inibiu o } \\
\text { crescimento de todas as cepas de Candida } \\
\text { estudadas, representando uma possibilidade } \\
\text { promissora para utilização clínica. }\end{array}$ & $\begin{array}{c}\text { Abílio et al. } \\
\text { (2014) }\end{array}$ \\
\hline
\end{tabular}




\begin{tabular}{|c|c|c|c|}
\hline Parte da planta & Tipo de estudo/Metodologia & Principais resultados & Referência \\
\hline Folha e/ou casca & $\begin{array}{l}\text { In vitro. As partes vegetais coletadas foram secas em } \\
\text { estufa de ventilação forçada a } 40^{\circ} \mathrm{C} \text { e moídas em } \\
\text { moinho de faca. Após, foi feito o extrato da planta por } \\
\text { maceração, à temperatura ambiente, utilizando } \\
\text { solução de água e etanol em proporções 30:70. Para } \\
\text { determinar MIC foi utilizada a técnica de microdiluição } \\
\text { em microplaca realizando sucessivas diluições dos } \\
\text { extratos com inóculo das bactérias e o diclugonato de } \\
\text { clorexidina a } 0,12 \% \text { utilizado como controle positivo. A } \\
\text { MBC foi realizada por meio de subcultivo em placas de } \\
\text { Petri, dos poços que não apresentaram crescimento } \\
\text { bacteriano. }\end{array}$ & $\begin{array}{l}\text { Constatou-se que todos os extratos vegetais } \\
\text { analisados apresentaram } \\
\text { atividade antimicrobiana para a maioria das } \\
\text { espécies de Streptococcus, } \\
\text { sendo todas sensíveis a, pelo menos, um extrato. } \\
\text { Os extratos que apresentaram os menores } \\
\text { valores de MIC e MBC foram os de } S \text {. } \\
\text { terebintifolius e de Syderoxylum obtusifolium. S. } \\
\text { parasanguis foi a espécie mais resistente contra } \\
\text { os extratos vegetais testados. }\end{array}$ & $\begin{array}{l}\text { Rocha et al. } \\
\text { (2013) }\end{array}$ \\
\hline $\begin{array}{c}\text { Cascas, folhas e } \\
\text { frutos }\end{array}$ & $\begin{array}{l}\text { In vitro. A casca da aroeira foi triturada em } \\
\text { liquidificador e após tamisada em malha para a } \\
\text { obtenção do pó. Para o extrato de folhas, essas foram } \\
\text { secas e colocadas em moinho de facas e ainda, } \\
\text { tamisadas em malha para a obtenção do pó. Após este } \\
\text { processo, o pó obtido foi fracionado e as soluções } \\
\text { obtidas foram aquecidas e agitadas. Após sete dias os } \\
\text { extratos foram filtrados a vácuo e envasados em } \\
\text { capela de fluxo laminar. Foi ainda extraído o UE do } \\
\text { fruto da aroeira por meio da hidrodestilação. O teste } \\
\text { bacteriano foi realizado sobre ágar MH, onde foram } \\
\text { utilizadas cepas de } E \text {. coli, E. faecalis, } P \text {. aeruginosa e } \\
\text { S. aureus. Foram utilizados discos com as substâncias } \\
\text { em placas que após ficarem em temperatura ambiente } \\
\text { por duas horas, foram incubadas a } 36^{\circ} \mathrm{C} \text { por } 24 \text { horas e } \\
\text { após os halos de inibição foram mensurados com } \\
\text { auxílio de um paquímetro digital. }\end{array}$ & $\begin{array}{c}\text { Para a E. coli, o extrato hidroalcoólico das folhas } \\
\text { da aroeira e o OE dos frutos da árvore } \\
\text { apresentaram atividade antibacteriana. Todas as } \\
\text { linhagens em teste foram sensíveis ao OE de } \\
\text { canela. Os extratos da casca da aroeira e de } \\
\text { canela não apresentaram atividade frente às } \\
\text { linhagens em teste, enquanto que o OE da canela } \\
\text { apresentou atividade em todas as linhagens. }\end{array}$ & $\begin{array}{c}\text { Greatti et al. } \\
\qquad(2014)\end{array}$ \\
\hline Frutas maduras & $\begin{array}{l}\text { In vitro. As amostras foram secas ao ar livre por uma } \\
\text { semana à temperatura ambiente, para que não } \\
\text { houvesse perda de componentes voláteis; } \\
\text { posteriormente, os frutos foram descascados e } \\
\text { submetidos à extração por hidrodestilação. Para as } \\
\text { análises, foram utilizadas bactérias Gram-negativas } \\
\text { como E. coli, } \text { K. oxytoca, Pseudomonas sp., } \\
\text { Enterobacter sp.; E. agglomerans e Gram-positivas } \\
\text { Streptococcus sp. grupo D, S. aureus, Corynebacterium } \\
\text { sp., Bacillus sp. e Nocardia sp. Na análise, amostras de } \\
\text { 100 } \mu \text { L de cada diluição de OE extraído, } 940 \mu \mathrm{L} \text { de meio } \\
\text { de cultura e } 10 \mu \mathrm{L} \text { de cada suspensão microbiana } \\
\text { foram amostradas. O teste foi realizado em triplicata, } \\
\text { onde a MIC foi definida como a menor concentração } \\
\text { de teste que inibiu o crescimento visível do } \\
\text { microrganismo testado (a turbidez do conteúdo do } \\
\text { tubo não foi verificada). }\end{array}$ & $\begin{array}{l}\text { Os resultados mostraram que o OE de frutos de } S \text {. } \\
\text { terebinthifolius foi ativo contra os } \\
\text { microrganismos testados. O óleo mostrou-se } \\
\text { particularmente ativo contra bactérias gram- } \\
\text { positivas Corynebacterium sp., Bacillus sp. e } \\
\text { Nocardia sp., cujos valores de MIC foram os } \\
\text { menores entre as bactérias testadas, enquanto } \\
\text { espécies Gram-negativas foram Enterobacter sp., } \\
\text { E. agglomerans, E. coli e } K \text {. oxytoca apresentaram } \\
\text { menor sensibilidade ao óleo (evidenciado pelos } \\
\text { maiores valores de MIC). }\end{array}$ & $\begin{array}{l}\text { Cole et al. } \\
\text { (2014) }\end{array}$ \\
\hline Folhas & $\begin{array}{l}\text { In vitro. Foram utilizadas folhas frescas de } S \text {. } \\
\text { terebinthifolius para a preparação do extrato, pelo } \\
\text { método de hidrodestilação. As atividades } \\
\text { antimicrobianas foram examinadas pelo método de } \\
\text { disco-difusão utilizando bactérias ( } S \text {. aureus, } P \text {. } \\
\text { aeruginosa e } E \text {. coli) e fungos ( } A \text {. niger, } A \text {. parasiticus e } \\
\text { C. albicans). O grau de inibição do crescimento foi } \\
\text { avaliado comparando-se com os controles (sulfato de } \\
\text { gentamicina e nistatina para bactérias e fungos, } \\
\text { respectivamente). }\end{array}$ & $\begin{array}{l}\text { Todas as amostras de } S \text {. terebinthifolius exibiram } \\
\text { atividade inibitória contra os microrganismos } \\
\text { utilizados. A baixa atividade observada contra } E \text {. } \\
\text { coli pode ser devido a lipopolissacarídeos na } \\
\text { membrana externa das bactérias Gram-negativas, } \\
\text { que as tornam resistentes a agentes externos. A } \\
\text { atividade antimicrobiana do OE de folhas frescas } \\
\text { pode ser atribuída à presença de compostos } \\
\text { biologicamente ativos. }\end{array}$ & $\begin{array}{c}\text { E-Massry et al. } \\
\text { (2009) }\end{array}$ \\
\hline $\begin{array}{l}\text { Partes diversas das } \\
\text { plantas }\end{array}$ & $\begin{array}{l}\text { In vitro. Plantas foram secas, esmagadas e peneiradas } \\
\text { até virarem pó, submetendo à extração a frio em } \\
\text { etanol a } 70 \% \text { durante } 5 \text { dias. O extrato foi filtrado com } \\
\text { papel filtro qualitativo, evaporados até o solvente ser } \\
\text { completamente removido. Extracto seco foi dissolvido } \\
\text { em etanol. Os extratos brutos foram testados contra } \\
\text { cepas padrão de } S \text {. aureus, B. subtilis, S. faecalis, } E \text {. } \\
\text { coli, } K \text {. pneumoniae, Mycobacterium smegmatis e } C \text {. } \\
\text { albicans, cultivadas em meio apropriado para cada } \\
\text { espécie, em placas de Petri. Discos de papel } \\
\text { embebidos com } 50 \mu \text { L de cada extrato foram colocados } \\
\text { em cada uma das placas de Petri com os organismos } \\
\text { para que a atividade fosse avaliada. Medições dos } \\
\text { halos de inibição foram realizadas. }\end{array}$ & $\begin{array}{c}\text { A maioria das espécies da Caatinga apresentou } \\
\text { atividade contra dois ou três microorganismos } \\
\text { diferentes, mas as espécies da Mata Atlântica } \\
\text { mostraram atividade de três a cinco } \\
\text { microrganismos. No entanto, embora as espécies } \\
\text { da Mata Atlântica apresentassem maior } \\
\text { versatilidade, não demonstraram forte potencial } \\
\text { para inibir microrganismos. De todas as espécies } \\
\text { estudadas em ambos os ambientes, apenas S. } \\
\text { terebinthifolius (Mata Atlântica) apresentou } \\
\text { maior versatilidade, inibindo cinco dos sete } \\
\text { microrganismos testados: } S . \text { aureus, S. faecalis, E. } \\
\text { coli, K. pneumoniae e M. smegmatis. }\end{array}$ & $\begin{array}{c}\text { Almeida et al. } \\
\text { (2011) }\end{array}$ \\
\hline
\end{tabular}




\begin{tabular}{|c|c|c|c|}
\hline Parte da planta & Tipo de estudo/Metodologia & Principais resultados & Referência \\
\hline Folhas & $\begin{array}{l}\text { In vitro. O OE da planta foi obtido por meio da } \\
\text { destilação de água usando Clevenger. A determinação } \\
\text { da MIC foi realizada pelo método padrão NCCL em } \\
\text { uma placa de } 96 \text { poços, sendo que em cada poço } \\
\text { foram adicionados o meio de cultura, amostra ou } \\
\text { antibiótico norfloxacino e o inóculo de } S \text {. aureus, } E \text {. } \\
\text { coli, ou C. albicans. Após a adição do inóculo, as placas } \\
\text { foram incubadas a } 36^{\circ} \mathrm{C} \text { para } S \text {. aureus e } E \text {. coli e } 30^{\circ} \mathrm{C} \\
\text { para } C \text {. albicans, por } 24 \mathrm{~h} \text {. Em seguida, foram } \\
\text { adicionados } 50 \mu \mathrm{L} \text { de cloreto de trifluoretrazólio (TTC) } \\
\text { (solução aquosa a } 0,5 \% \text { ). Após } 4 \mathrm{~h} \text { de incubação, a MIC } \\
\text { foi determinada na menor concentração capaz de } \\
\text { inibir o crescimento visível das células determinadas } \\
\text { pelo TTC. }\end{array}$ & $\begin{array}{l}\text { Todos os extratos apresentaram forte atividade } \\
\text { antimicrobiana contra } S \text {. aureus e } E \text {. coli. O estudo } \\
\text { sugere que a folha de } S \text {. terebinthifolius contém } \\
\text { substâncias antibacterianas promissoras para uso } \\
\text { em infecções do trato urinário e outras. }\end{array}$ & $\begin{array}{l}\text { Uliana et al. } \\
\text { (2016) }\end{array}$ \\
\hline Folhas & $\begin{array}{l}\text { In vitro. As folhas foram secas e após trituradas até se } \\
\text { transformarem em pó para obter o extrato. O inóculo } \\
\text { de BCMV (Bean Common Mosaic Virus) utilizado ao } \\
\text { longo das experiências consistiu em tecido de folha de } \\
\text { feijão infectado moído em tampão fosfato de potássio } \\
\text { 0,01M, pH 7,0, contendo 0,002M de ácido } \\
\text { etilenodiaminotetracético (EDTA) (1g de tecido por } \\
50 \mathrm{~mL} \text { de tampão fosfato de potássio). Foram } \\
\text { colocados, em } 6 \text { potes, volumes iguais de extratos } \\
\text { aquosos de folhas de feijão infectadas com vírus e } \\
\text { extratos de plantas foram misturados e mantidos à } \\
\text { temperatura ambiente ( } 28^{\circ} \mathrm{C} \text { ) por } 10 \text { min. A mistura foi } \\
\text { inoculada em plantas de feijão saudáveis com oito dias } \\
\text { de idade. A percentagem de infecção e a inibição do } \\
\text { vírus em comparação com o controle foram calculadas } \\
\text { com base nos sintomas visíveis. }\end{array}$ & $\begin{array}{l}\text { As porcentagens inibitórias do BCMV utilizando } \\
\text { extratos vegetais de Azadirachta indica, } \\
\text { Clerodendrum inerme e S. terebinthifolius foram } \\
(90 \%, 89 \%),(89 \%, 86 \%) \text { e }(84 \%, 82 \%) \\
\text { respectivamente. Extratos vegetais de } \\
\text { Plectranthus tenuiflorus, Mirabilis jalapa e A. } \\
\text { indica registraram as maiores taxas de inibição } \\
\text { em todas as concentrações, seguido do extrato de } \\
\text { C. inerme. A menor taxa inibitória foi obtida com } \\
\text { o extrato de } S \text {. terebinthifolius. }\end{array}$ & $\begin{array}{c}\text { Elsharkawy et } \\
\text { al. (2015) }\end{array}$ \\
\hline Casca do caule & $\begin{array}{l}\text { In vitro. Feita tintura da casca do caule de } S \text {. } \\
\text { terebinthifolius, determinou-se a MIC da tintura pela } \\
\text { técnica de microdiluição utilizando uma placa com o } \\
\text { fundo em U de } 96 \text { cavidades; inicialmente, } 100 \mu \mathrm{L} \text { de } \\
\text { meio de cultura duplamente concentrado foram } \\
\text { distribuídos nos poços da placa. Em seguida, } 100 \mu \mathrm{L} \text { da } \\
\text { tintura foram distribuídos em uma concentração inicial } \\
\text { de } 5.000 \mu \mathrm{g} / \mathrm{mL} \text {, a partir dessas concentrações foram } \\
\text { realizadas diluições seriadas retirando-se uma } 100 \mathrm{~mL} \\
\text { do meio mais concentrado e inserindo-o no seguinte } \\
\text { poço. Após, foram distribuídos } 10 \mu \mathrm{L} \text { de inóculo nos } \\
\text { poços de cada coluna. Os testes foram realizados em } \\
\text { triplicata e as placas foram incubados a } 35 \text { durante } \\
\text { 48h. A leitura para determinar a MIC da tintura na } \\
\text { cepa de levedura foi feita pelo método visual. A } \\
\text { formação (ou não) de aglomerados celulares no fundo } \\
\text { dos poços foi levada em consideração. }\end{array}$ & $\begin{array}{l}\text { Quanto a curva de crescimento bacteriano, } S \text {. } \\
\text { terebinthifolius foi capaz de reduzir } \\
\text { significativamente o número de UFC/mL quando } \\
\text { comparado ao controle do crescimento até o } \\
\text { tempo de } 60 \text { min. } S \text {. terebinthifolius } \\
\text { possivelmente atua na parede celular fúngica, } \\
\text { uma vez que o teste de sorbitol indicou uma MIC } \\
\text { de } 1250 \mathrm{mg} / \mathrm{mL} \text {. Na morfologia fúngica, observou- } \\
\text { se redução de pseudo-hifas, clamidoconídios e } \\
\text { blastoconídios na presença do produto } \\
\text { experimental. Notou-se que } S \text {. terebinthifolius } \\
\text { apresentou atividade antifúngica contra } C \text {. } \\
\text { albicans, inibindo, provavelmente, a formação da } \\
\text { parede celular fúngica. }\end{array}$ & $\begin{array}{c}\text { Alves et al. } \\
\text { (2013) }\end{array}$ \\
\hline $\begin{array}{l}\text { Partes diversas das } \\
\text { plantas }\end{array}$ & $\begin{array}{l}\text { In vitro. Foram utilizados extratos de quatro plantas } \\
\text { para testar a ação em bactéria E. faecalis. Foram } \\
\text { colocadas quantidades de meio de cultura em placas } \\
\text { de Petri e após sua solidificação, as suspensões } \\
\text { microbianas foram inoculadas em cada placa com } \\
\text { auxílio do swab para evitar o crescimento de colônias } \\
\text { isoladas. Posteriormente, foram confeccionados, em } \\
\text { cada placa, seis poços de tamanho padrão no ágar e } \\
\text { com uma seringa eles foram preenchidos com o } \\
\text { inóculo. Mantiveram-se as placas de Petri à } \\
\text { temperatura ambiente por } 2 \text { horas e posteriormente, } \\
\text { incubadas a } 37^{\circ} \mathrm{C} \text { por } 48 \text { horas. Após, as placas foram } \\
\text { analisadas, sendo medidos em milímetros os halos de } \\
\text { inibição do crescimento microbiano formados no ágar. }\end{array}$ & $\begin{array}{l}\text { A quixabeira apresentou os menores halos de } \\
\text { inibição, por outro lado os extratos vegetais } \\
\text { aroeira-do-sertão e aroeira-da-praia ( } S \text {. } \\
\text { terebinthifolius), na concentração } 100 \% \text {, } \\
\text { induziram halos maiores do que o } \mathrm{NaOCl} \text { a } 2,5 \% \text {, } \\
\text { com diferença estatisticamente significativa. A } \\
\text { aroeira-do-sertão e a aroeira-da-praia } \\
\text { apresentaram halos de inibição contra o } E \text {. } \\
\text { faecalis superiores aos demais extratos vegetais } \\
\text { testados, em todas as concentrações. }\end{array}$ & $\begin{array}{c}\text { Costa et al. } \\
\text { (2010) }\end{array}$ \\
\hline
\end{tabular}




\begin{tabular}{|c|c|c|c|}
\hline Parte da planta & Tipo de estudo/Metodologia & Principais resultados & Referência \\
\hline Folhas & $\begin{array}{l}\text { In vitro. Os OEs foram extraídos pelo método de } \\
\text { hidrodestilação por } 3 \text { horas em aparelho Clevenger. As } \\
\text { atividades antibacterianas foram avaliadas pela } \\
\text { difusão em disco de ágar e os métodos de } \\
\text { microdiluição contra } \text { S. aureus, B. cereus e } E \text {. coli. } \\
\text { Resumidamente, uma amostra do microrganismo } \\
\text { testado ( } 2 \times 108 \mathrm{UFC} \mathrm{mL}-1) \text {, previamente ativada } \\
\text { duas vezes em intervalos de } 24 \mathrm{~h} \text {, foi espalhada em } \\
\text { placas de Petri com ágar } \mathrm{MH} \text {. Discos de papel de filtro } \\
\text { ( } 6 \mathrm{~mm} \text { de diâmetro) foram impregnados } \\
\text { individualmente com } 5 \mu \mathrm{L} \text { dos óleos essenciais e } \\
\text { colocados nas placas inoculadas. As placas foram } \\
\text { incubadas por } 48 \text { horas a } 37^{\circ} \mathrm{C} \text { nos casos de } S \text {. aureus e } \\
\text { E. coli e a } 32^{\circ} \mathrm{C} \text { para } B \text {. cereus. Os diâmetros das zonas } \\
\text { de inibição foram medidos usando um parâmetro e } \\
\text { expressos em milímetros. }\end{array}$ & $\begin{array}{l}\text { Os óleos de todas as espécies testadas, exceto a } \\
\text { de Anacardium occidentale, exibiram níveis } \\
\text { variáveis de atividade antibacteriana contra } \\
\text { bactérias gram-positivas e gram-negativas. Em } \\
\text { geral, as zonas de inibição foram maiores para } \\
\text { bactérias gram-positivas. Óleo de julho de } S \text {. } \\
\text { terebinthifolius foi mais ativo contra todas as } \\
\text { estirpes bacterianas do que o óleo } \\
\text { correspondente extraído em março. }\end{array}$ & $\begin{array}{l}\text { Montanari et } \\
\text { al. (2012) }\end{array}$ \\
\hline Casca do caule & $\begin{array}{l}\text { In vitro. O extrato hidroalcoólico foi obtido por } \\
\text { método de infusão, com imersão de } 200 \mathrm{~g} \text { de material } \\
\text { vegetal seco em } 1000 \mathrm{~mL} \text { de álcool etílico a } 70 \% \text { por } \\
\text { cinco dias; após o extrato foi filtrado e embalado em } \\
\text { frascos de vidro âmbar e armazenado em ambiente de } \\
\text { baixa luminosidade. Inóculos foram semeados em } \\
\text { placas de ágar } \mathrm{MH} \text { (E. faecalis, E. coli, P. aeruginosa e } \\
\text { S. aureus), ágar sangue (S. mutans) e ágar Sabouraud } \\
\text { (Candida spp.) utilizando swab pela técnica de } \\
\text { depleção. Dez discos foram colocados em cada placa, } \\
\text { onde cada um recebeu } 10 \mathrm{~mL} \text { de extrato com a ajuda } \\
\text { de uma micropipeta. As placas foram incubadas em } \\
\text { cultura a } 37^{\circ} \mathrm{C} \text { por } 48 \text { horas, tempo em que a leitura } \\
\text { dos halos de inibição foi realizada, utilizando duas } \\
\text { medidas perpendiculares com pinças digitais. }\end{array}$ & $\begin{array}{l}\text { E. faecalis mostrou sensibilidade à aroeira-da- } \\
\text { praia, mororó, angico, bom-nome e umbuzeiro, e } \\
\text { extrato de bom-nome apresentou a maior média } \\
\text { de halo de inibição com } 8,3 \mathrm{~mm} \text {. O S. aureus não } \\
\text { apresentou sensibilidade apenas para a } \\
\text { embiratanha e urtiga-branca. Nenhuma } \\
\text { substância mostrou atividade antimicrobiana } \\
\text { contra o } P \text {. aeruginosa, } S \text {. mutans e a } C \text {. tropicalis. }\end{array}$ & $\begin{array}{l}\text { Costa et al. } \\
(2013)\end{array}$ \\
\hline $\begin{array}{l}\text { Partes diversas das } \\
\text { plantas }\end{array}$ & $\begin{array}{l}\text { In vitro. Os extratos de } \text { S. terebinthifolius e } S \text {. } \\
\text { obtusifolium foram obtidos por percolação e imersão } \\
\text { das plantas em solução hidroalcoólica } 70 \% \text { por } 72 \\
\text { horas; após, os compostos foram filtrados e } \\
\text { armazenados em ambiente escuro a temperatura } \\
\text { ambiente. A ação antimicrobiana das plantas foi } \\
\text { avaliada contra a bactéria } E \text {. faecalis por meio de } \\
\text { difusão por ágar. Em placas de Petri com o meio de } \\
\text { cultura foram colocados inóculos de E. faecalis. Os } \\
\text { halos de inibição foram mensurados após } 48 \text { horas, } \\
\text { com as placas a } 37^{\circ} \mathrm{C} \text {. }\end{array}$ & $\begin{array}{l}\text { As duas plantas utilizadas no estudo mostraram } \\
\text { efeito antibacteriano conta } E \text {. faecalis. } S \text {. } \\
\text { terebinthifolius mostrou ação em todas as } \\
\text { concentrações utilizadas do extrato, com } \\
\text { diferenças significativas comparada com a } S \text {. } \\
\text { obtusifolium. Os resultados sugerem que as duas } \\
\text { plantas analisadas se mostram uma opção } \\
\text { terapêutica na lista de agentes alternativos para } \\
\text { tratamentos endodônticos. }\end{array}$ & $\begin{array}{l}\text { Costa et al. } \\
\text { (2012) }\end{array}$ \\
\hline $\begin{array}{l}\text { Partes diversas das } \\
\text { plantas }\end{array}$ & $\begin{array}{l}\text { In vitro. Os extratos das plantas foram submetidos à } \\
\text { extração por maceração, agitação. filtração e } \\
\text { liofilização. Os organismos utilizados nesse estudo } \\
\text { foram: } C \text {. albicans, } S \text {. mutans, } S \text {. aureus e } A \text {. } \\
\text { actinomycetemcomitans. Os métodos utilizados para a } \\
\text { análise foram microdiluição e difusão em ágar } \\
\text { específico para cada espécie. Os microrganismos } \\
\text { foram incubados a } 37^{\circ} \mathrm{C} \text { por } 18 \mathrm{~h} \text { em sistema } \\
\text { anaeróbico. Discos estéreis foram embebidos em } 20 \mu \mathrm{L} \\
\text { das frações vegetais e aplicados na superfície do ágar } \\
\text { previamente semeada com o microrganismo. Os } \\
\text { controles incluíram discos contendo } 10 \mu \mathrm{gg} / \mathrm{mL} \text { de } \\
\text { cloranfenicol para bactérias e } 20 \mu \mathrm{mg} / \mathrm{mL} \text { de nistatina } \\
\text { para levedura, e também } 10 \mu \mathrm{gg} / \mathrm{mL} \text { de dimetil } \\
\text { sulfóxido. Após } 48 \mathrm{~h} \text { de incubação a } 37^{\circ} \mathrm{C} \text {, os } \\
\text { diâmetros das zonas de inibição foram medidos e } \\
\text { comparados. }\end{array}$ & $\begin{array}{c}\text { Os resultados mostraram que todos os extratos } \\
\text { apresentam atividade antimicrobiana significativa } \\
\text { contra todas as espécies bacterianas avaliadas, } \\
\text { com exceção das frações hexano butanal e } \\
\text { butanal de } S \text {. terebinthifolius para } C \text {. albicans e } A \text {. } \\
\text { actinomycetemcomitans. A cepa bacteriana mais } \\
\text { sensível foi a S. mutans, seguido de } S \text {. aureus, } \\
\text { enquanto que } A \text {. actinomycetemcomitans foi } \\
\text { menos sensível. }\end{array}$ & $\begin{array}{l}\text { Pereira et al. } \\
\qquad(2011)\end{array}$ \\
\hline $\begin{array}{l}\text { Frutos (em três } \\
\text { estágios: imaturo, } \\
\text { quase maduro e } \\
\text { maduro) }\end{array}$ & $\begin{array}{l}\text { In vitro. Os frutos foram secos a temperatura } \\
\text { ambiente durante uma semana e após triturados em } \\
\text { pó, após foram submetidos a hidrodestilação por } 2 \mathrm{~h} \\
\text { usando um aparelho do tipo Clevenger. Para as } \\
\text { análises de propriedades antibacterianas, quatro } \\
\text { linhagens bacterianas, } E \text {, feacium e } S \text {. agalactiae, } E \text {. } \\
\text { coli e } S \text {. typhymurium, essas sendo cultivadas em meio } \\
\text { ágar } \mathrm{MH} \text {. Na análise, uma suspensão do organismo } \\
\text { testado foi espalhada na placa de meio sólido } \mathrm{MH} \text {. } \\
\text { Disco de papel de filtro foi ensopado com } 15 \mu \mathrm{L} \text { dos } \\
\text { OEs e colocados nas placas inoculadas. Depois de } \\
\text { serem mantidos a } 4^{\circ} \mathrm{C} \text { por } 2 \mathrm{~h} \text {, eles foram incubados a } \\
37^{\circ} \mathrm{C} \text { por } 24 \mathrm{~h} \text {. As dimensões da zona de inibição do } \\
\text { disco de papel foram medidas com precisão. }\end{array}$ & $\begin{array}{l}\text { Em geral, as cepas mais sensíveis foram as gram } \\
\text { positivas } S \text {. agalactiae e } E \text {. faecium que foram } \\
\text { particularmente sensíveis aos OEs emitidos a } \\
\text { partir dos frutos maduros. E. coli e } S \text {. typhimurium } \\
\text { Gram-negativas foram menos suscetíveis a todos } \\
\text { os óleos essenciais examinados. A resistência } \\
\text { relativa de bactérias gram-negativas a OEs } \\
\text { contribuiu para a ocorrência de um } \\
\text { lipopolissacarídeo muito restritivo contendo } \\
\text { membrana externa. }\end{array}$ & $\begin{array}{l}\text { Ennigrou et al. } \\
\qquad(2017)\end{array}$ \\
\hline
\end{tabular}




\begin{tabular}{|c|c|c|c|}
\hline Parte da planta & Tipo de estudo/Metodologia & Principais resultados & Referência \\
\hline Frutos & $\begin{array}{l}\text { In vitro. Casca do fruto foi submetida a extração por } \\
\text { maceração estática e filtrada duas vezes por semana. } \\
\text { O extrato foi evaporado a } 35^{\circ} \mathrm{C} \text { em banho maria em } \\
\text { local sem luminosidade. Foi avaliada a inibição do } \\
\text { crescimento de microbactérias usando placa de } 96 \\
\text { poços. Inicialmente, uma suspensão de } M \text {. bovis foi } \\
\text { incubada com meio Middlebrook } 7 \mathrm{H} 9 \text { suplementado } \\
\text { com Tween } 80 \text { a } 0,05 \% \text { e ADC (Albumina Dextrose } \\
\text { Catalase).; a placa foi incubada a } 37^{\circ} \mathrm{C} \text { por sete dias. } \\
\text { Após esse período, a solução de MTT foi incubada } \\
\text { durante } 3 \text { h e foi adicionado o tampão de lise em água } \\
\text { destilada. A placa foi incubada novamente durante a } \\
\text { noite e a leitura foi realizada utilizando um } \\
\text { espectrofotômetro a } 570 \text { nm. Como controle positivo, } \\
\text { M. bovis tratado com antibiótico rifampicina; controle } \\
\text { negativo utilizou-se } M \text {. bovis. }\end{array}$ & $\begin{array}{c}\text { O extrato metanólico de } \text { S. terebinthifolius, a } \\
\text { fração A3 e a apigenina inibiram a produção de } \\
\text { óxido nítrico por macrófagos estimulados por LPS } \\
\text { e apresentaram alta atividade antioxidante. } \\
\text { Mostraram baixa toxicidade aos macrófagos RAW } \\
\text { 264.7. Essas atividades juntas poderiam contribuir } \\
\text { para toda a atividade anti-inflamatória descrita } \\
\text { para S. terebinthifolius e para seu uso } \\
\text { etnofarmacológico. }\end{array}$ & $\begin{array}{l}\text { Bernardes et } \\
\text { al. (2014) }\end{array}$ \\
\hline Cascas do caule & $\begin{array}{l}\text { In vitro. O material coletado foi separado em estufa e } \\
\text { triturado em moinho de corte. Após, o extrato foi } \\
\text { obtido por meio da maceração com etanol a } 70 \% \text {, por } \\
24 \mathrm{~h} \text {, em temperatura ambiente. Para determinar a } \\
\text { suscetibilidade de St. mutans aos extratos das espécies } \\
\text { vegetais selecionadas, utilizou-se o método de difusão } \\
\text { em ágar, onde perfuraram-se os meios em alguns } \\
\text { pontos na placa para serem colocados os inóculos e os } \\
\text { extratos das plantas. As placas foram incubadas a } \\
35,5^{\circ} \mathrm{C} \text { em estufa bacteriológica por } 24 \mathrm{~h} \text { e então foram } \\
\text { observados se havia a formação de halo nos poços, } \\
\text { esses sendo medidos. }\end{array}$ & $\begin{array}{l}\text { Os extratos hidroalcoólicos de } P \text {. granatum, } \\
\text { Psidium guajava e S. terebinthifolius } \\
\text { apresentaram atividade antimicrobiana contra } S . \\
\text { mutans. Os extratos hidroalcoólicos de } \\
\text { Chenopodium ambrosioides não demonstraram } \\
\text { efeito antimicrobiano em qualquer das } \\
\text { concentrações testadas. }\end{array}$ & $\begin{array}{l}\text { Vieira et al. } \\
\qquad(2014)\end{array}$ \\
\hline \multicolumn{4}{|c|}{ Uncaria tomentosa Willd ex Schult } \\
\hline $\begin{array}{c}\text { Diversas partes } \\
\text { das plantas }\end{array}$ & $\begin{array}{l}\text { In vitro. As plantas foram picadas e embebidas em } \\
\text { etanol absoluto. As misturas foram filtradas e } \\
\text { evaporadas a até seu uso. Para a análise da atividade } \\
\text { antibacteriana dos extratos, utilizou-se o método de } \\
\text { difusão em placa com ágar com o inóculo da } \\
\text { suspensão bacteriana, inserida em pequenos poços no } \\
\text { ágar. Estes foram preenchidos com } 100 \mu \mathrm{L} \text { do extrato } \\
\text { etanólico correspondente. No final do período, as } \\
\text { zonas de inibição formadas foram medidas em } \\
\text { milímetros usando o vernier. As zonas de inibição com } \\
\text { menos de } 12 \text { mm de diâmetro não foram consideradas } \\
\text { para a análise da atividade antibacteriana. }\end{array}$ & $\begin{array}{l}\text { Os extratos de Chuchuhuasi, Jergon Sacha, } \\
\text { Tahuari, Eucalipto e Unha-de-gato exibiram } \\
\text { atividade antibacteriana favorável contra } P \text {. } \\
\text { aeruginosa. O efeito inibitório dos extratos sobre } \\
\text { as cepas de } P \text {. aeruginosa testadas demonstrou } \\
\text { que Tabebuia impetiginosa e Maytenus } \\
\text { macrocarpa possuem maior atividade } \\
\text { antibacteriana. }\end{array}$ & $\begin{array}{l}\text { Ulloa-Urizar et } \\
\text { al. (2015) }\end{array}$ \\
\hline Casca do caule & $\begin{array}{l}\text { In vitro. As cascas foram colocadas em moinho de } \\
\text { corte e após o extrato foi preparado por maceração } \\
\text { dinâmica, agitação e filtragem. A atividade antifúngica } \\
\text { foi realizada pelo método microdiluição em caldo, } \\
\text { sendo cada poço contendo inoculados de células de } \\
\text { levedura e o respectivo composto de teste. As placas } \\
\text { foram incubadas a } 35^{\circ} \mathrm{C} \text { por } 48 \mathrm{~h} \text {. O ensaio foi realizado } \\
\text { em triplicata. A MIC foi definida como a menor } \\
\text { concentração de amostra na qual o microrganismo } \\
\text { testado não demonstrou crescimento visível. }\end{array}$ & $\begin{array}{l}\text { Os resultados permitem estabelecer } \\
\text { consistentemente a atividade antifúngica da } \\
\text { polifenol rica em água insolúvel e da fração pouco } \\
\text { estudada da casca de } U \text {. tomentosa contra } \\
\text { algumas espécies de Candida não-albicans } \\
\text { selecionadas. A inibição superior do crescimento } \\
\text { celular parece estar relacionada à morfologia da } \\
\text { parede celular e alterações químicas. }\end{array}$ & $\begin{array}{l}\text { Moraes et al. } \\
\text { (2015) }\end{array}$ \\
\hline Gel 2\% & $\begin{array}{l}\text { In vitro. Espécimes de } E \text {. faecalis foram subcultivados } \\
\text { em Placas de ágar BHI-sangue para obter colônias } \\
\text { frescas. Quarenta e oito pré-molares humanos foram } \\
\text { contaminados individualmente por } 21 \text { dias em tubos } \\
\text { contendo } 5 \mathrm{~mL} \text { de suspensão de } E \text {. faecalis. Os } \\
\text { espécimes foram divididos aleatoriamente em quatro } \\
\text { grupos de acordo com o produto utilizado durante a } \\
\text { preparação quimiomecânica (PQM): grupo CC (com } \\
\text { extrato de U. tomentosa); grupo CHX; grupo NaOCl; } \\
\text { grupo SS. Amostras microbiológicas foram coletadas } \\
\text { antes (S1) e após (S2) CMP e após } 7 \text { dias (S3). } \\
\text { Unidades formadoras de colônias (UFC/mL) nos } \\
\text { diferentes tempos de amostragem foram analisadas } \\
\text { estatisticamente. }\end{array}$ & $\begin{array}{l}\text { Os resultados mostram que não há diferença } \\
\text { significativa entre } \mathrm{S} 3 \text { e } \mathrm{S} 2(\mathrm{p}>0,05) \text { nos grupos } \mathrm{CC} \\
\text { e } \mathrm{CHX} \text {. A carga bacteriana foi maior nas amostras } \\
\mathrm{S} 3 \text { do que nas amostras } \mathrm{S} 2(\mathrm{p}<0,05) \text { nos grupos } \\
\mathrm{NaOCl} \text { e } \mathrm{SS} \text {. Os resultados sugerem efeito } \\
\text { antibacteriano do grupo } \mathrm{CC} \text { contra } E \text {. faecalis em } \\
\text { dentina infectada, além de antibacteriana } \\
\text { substantividade de } \mathrm{CC} \text { e } \mathrm{CHX} \text { até } 7 \text { dias. }\end{array}$ & $\begin{array}{l}\text { Herrera et al. } \\
\qquad(2016)\end{array}$ \\
\hline
\end{tabular}


REMPEL, C.; MACIEL, M. J.; BERGMANN, P. C.; MORÁS, A. P.; GOETTENS, C.

\begin{tabular}{|c|c|c|c|}
\hline Parte da planta & Tipo de estudo/Metodologia & Principais resultados & Referência \\
\hline Caule & $\begin{array}{l}\text { In vitro. Partes do caule foram submetidas ao processo } \\
\text { de maceração para preparação do extrato; foram } \\
\text { utilizadas linhagens padronizadas de microrganismos } \\
\text { Candida. A atividade antimicrobiana e determinação } \\
\text { da MIC do extrato da U. tomentosa foi feita pela } \\
\text { técnica de ágar-difusão em placas de Petri, meio sólido } \\
\text { Agar MH - DIFCO. Os mesmos procedimentos foram } \\
\text { realizados com a clorexidina em concentração } 0,12 \% \text {, } \\
\text { um antisséptico oral utilizado como controle positivo } \\
\text { nos experimentos. }\end{array}$ & $\begin{array}{c}\text { Os resultados deste estudo demonstram que a } U \text {. } \\
\text { tomentosa possui compostos bioativos com } \\
\text { atividade antimicrobiana sobre fungos do gênero } \\
\text { Candida, responsáveis pelas manifestações de } \\
\text { candidíase bucal. }\end{array}$ & $\begin{array}{l}\text { Souza Junior. } \\
\text { et al. (2011) }\end{array}$ \\
\hline Folhas e caule & $\begin{array}{l}\text { In vitro. Para a avaliação da atividade antimicrobiana } \\
\text { dos extratos secos e hidroalcoólicos de U. tomentosa, } \\
\text { foram utilizadas bactérias Gram-positivas e Gram- } \\
\text { negativas. No teste de diluição foram inoculados } \\
0,1 \mathrm{~mL} \text { da suspensão microbiana em uma série de } \\
\text { tubos contendo extratos de } U \text {. tomentosa. Após } 24 \\
\text { horas de incubação a } 37^{\circ} \mathrm{C} \text {, foram examinados } \\
\text { visualmente para comprovação da turvação. Os tubos } \\
\text { visivelmente límpidos foram considerados positivos. } \\
\text { Em seguida foram transferidos } 0,1 \text { mL para placas } \\
\text { contendo ágar BHI para determinação da } \\
\text { Concentração Microbicida Mínima (MMC). Após } \\
\text { incubação fez-se a leitura através da contagem de } \\
\text { colônias para verificação da presença ou ausência do } \\
\text { crescimento microbiano. }\end{array}$ & 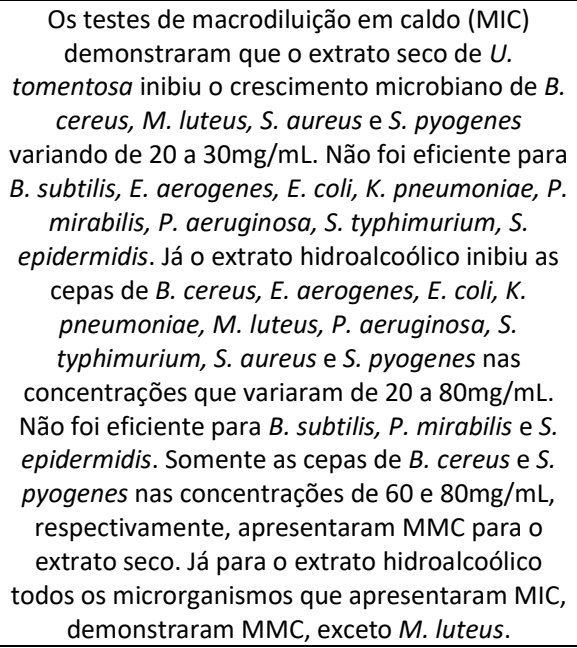 & Sá et al. (2014) \\
\hline Planta & $\begin{array}{l}\text { In vitro e In vivo. } 50 \text { pacientes foram distribuídos } \\
\text { aleatoriamente em } 1 \text { dos } 3 \text { grupos experimentais da } \\
\text { seguinte forma: grupo M (controle positivo), } 2 \% \text { gel de } \\
\text { miconazol e gel de tarina; grupo P (grupo placebo), } \\
\text { hidroxietilcelulose 1,5\% Natrosol; e grupo UT (grupo } \\
\text { experimental), } 2 \% \text { gel de U. tomentosa. Os pacientes } \\
\text { não sabiam qual tratamento receberiam. Todos } \\
\text { aplicaram o gel na base das dentaduras após as } \\
\text { refeições, por uma semana. Para cada paciente, a } \\
\text { Candida foi coletada todas as semanas por meio de } \\
\text { esfregaços orais ao longo da mucosa palatina e na } \\
\text { superfície do tecido da prótese superior. Cada swab foi } \\
\text { colocado em um tubo de ensaio contendo } 5 \text { mL de } \\
\text { meio de infusão Brain-Heart. Uma amostra desta } \\
\text { suspensão foi plaqueada em ágar Sabouraud, outros } \\
\text { foram colocados em HiCrome Candida Agar, e ambas } \\
\text { as placas foram incubadas. Um contador de colônia } \\
\text { digital quantificou as colônias e determinou o número } \\
\text { de unidades formadoras de colônia por mililitro (UFC / } \\
\text { mL). }\end{array}$ & $\begin{array}{l}\text { U. tomentosa gel foi um tratamento adjuvante } \\
\text { tópico eficaz (isto é, teve o mesmo efeito que } 2 \% \\
\text { zole gel); no entanto, a influência dos métodos de } \\
\text { higiene prescritos deve ser avaliada em estudos } \\
\text { futuros. Além disso, } U \text {. tomentosa, como } \\
\text { tratamento fitoterápico, pode ser mais } \\
\text { econômico do que outros tratamentos para } \\
\text { pacientes. }\end{array}$ & $\begin{array}{l}\text { Tay et al. } \\
(2014)\end{array}$ \\
\hline $\begin{array}{c}\text { Gel feito a partir } \\
\text { da planta }\end{array}$ & $\begin{array}{l}\text { In vitro. Quatro substâncias auxiliares foram avaliadas: } \\
\text { gel de } 2 \% \text { de } \mathrm{CHX} \text {, gel de } 2 \% \text { de } \mathrm{CC} \text { ( } U \text {. tomentosa), gel } \\
\text { de } 2 \% \text { de } \mathrm{CHX}+2 \% \text { de } \mathrm{CC}(1: 1 / \mathrm{v} \text { : v) e gel de } 1 \% \text { de } \\
\text { hidroxietilcelulose (NAT) (controle negativo). Os } \\
\text { microrganismos utilizados no estudo foram } E n \text {. } \\
\text { faecalis, S. aureus e } C \text {. albicans. Em seguida, } 100 \mu \mathrm{l} \text { de } \\
\text { cada suspensão microbiana foram banhados com } \\
\text { swab em ágar } \mathrm{MH} \text { e incubadas para secagem. Cada um } \\
\text { dos poços foi preenchido com uma substância de teste } \\
\text { (CHX, CC ou CHX + CC) ou o controle negativo (NAT). } \\
\text { Os meios foram incubados e, após, o que possuem } \\
\text { zonas de inibição em torno de poços contendo as } \\
\text { substâncias investigadas foram medidas com um } \\
\text { paquímetro digital. }\end{array}$ & $\begin{array}{c}\text { O diâmetro médio das zonas de inibição do } \\
\text { crescimento microbiano de } 2 \% \text { de } \mathrm{CHX}+\mathrm{CC} \\
\text { contra as estirpes microbianas testadas variou de } \\
21,7 \text { a } 33,5 \mathrm{~mm} \text {. Foi a substância mais eficaz } \\
\text { contra } E \text {. faecalis e } C \text {. albicans, seguida por } \mathrm{CHX} \text { e } \\
\text { CC. } \mathrm{CHX}+\mathrm{CC} \text {, CHX e CC tiveram atividade } \\
\text { antimicrobiana semelhante contra S. aureus (P> } \\
\text { 0,05). Como esperado, o NAT não teve efeito } \\
\text { inibitório. }\end{array}$ & $\begin{array}{l}\text { Herrera et al. } \\
\qquad(2010)\end{array}$ \\
\hline
\end{tabular}




\begin{tabular}{|c|c|c|c|}
\hline Parte da planta & Tipo de estudo/Metodologia & Principais resultados & Referência \\
\hline $\begin{array}{l}\text { Folhas, caules, } \\
\text { casca e madeira }\end{array}$ & $\begin{array}{l}\text { In vitro. O material vegetal, após coletado, foi seco, } \\
\text { moído e conservado em recipientes de plástico } \\
\text { material cujo foi utilizado para a extração do OE. A } \\
\text { atividade antimicrobiana dos extratos fenólicos foi } \\
\text { avaliada em S. aureus, E. faecalis e P. aeruginosa, que } \\
\text { são bactérias características da cavidade e o sistema } \\
\text { respiratório. Os ensaios antibacterianos foram } \\
\text { realizados usando um método de microdiluição em } \\
\text { placas de } 96 \text { poços. Porcentagens de inibição das } \\
\text { diferentes concentrações de extrato foram calculados } \\
\text { comparando o crescimento do controle com aqueles } \\
\text { obtidos de culturas com extratos fenólicos. As curvas } \\
\text { de dose-resposta (\% de inibição versus concentração } \\
\text { de extrato) foram estabelecidas para cada extrato e foi } \\
\text { calculada a concentração necessária para obter } 50 \% \\
\text { de inibição do crescimento (i.e., valor de IC50). Para } \\
\text { cada cepa bacteriana, os extratos foram testados em } \\
\text { dois experimentos independentes e em cada } \\
\text { experimento as diferentes doses do extrato foram } \\
\text { analisadas em duplicata. }\end{array}$ & $\begin{array}{l}\text { Extratos fenólicos de } U \text {. tomentosa exibiam } \\
\text { razoável capacidade antioxidante [valores de } \\
\text { ORAC (Oxigen Radical Absorbance Capacity) entre } \\
1,5 \text { e } 18,8 \mathrm{mmol} \mathrm{TE} / \mathrm{g} \text { ] e atividade antimicrobiana } \\
\text { contra potenciais patógenos respiratórios (IC50 } \\
\text { mínimo de } 133 \mu \mathrm{g} / \mathrm{mL} \text { ). Os resultados mostram } \\
\text { as particularidades da } U \text {. tomentosa } \\
\text { proantocianidinas e sugerir o valor potencial } \\
\text { desses extratos com o uso prospectivo como } \\
\text { ingredientes funcionais. }\end{array}$ & $\begin{array}{c}\text { Navarro-Hoyos } \\
\text { et al. (2017) }\end{array}$ \\
\hline Planta & $\begin{array}{l}\text { In vitro e In vivo. Uma mulher de } 64 \text { anos, usuária de } \\
\text { prótese dentária, foi submetida aos testes e análises } \\
\text { da pesquisa. Primeiramente foi feita uma anamnese } \\
\text { contendo sua idade, sexo, raça, medicamentos, } \\
\text { doenças e hábitos. Após, considerou-se saudável. } \\
\text { Além disso, a paciente estava na menopausa desde os } \\
53 \text { anos. Ao exame clínico, o palato apresentava } \\
\text { mucosa eritematosa, indicando DS (Denture } \\
\text { Stomatitis) tipo II. Um swab foi utilizado para retirar } \\
\text { amostra da mucosa palatal da paciente; cada swab foi } \\
\text { colocado em um tubo de ensaio. Uma amostra desta } \\
\text { suspensão foi espalhada em ágar Hi-crome Candar e } \\
\text { incubada a } 37^{\circ} \mathrm{C} \text { por } 48 \text { horas. As colônias foram } \\
\text { contadas e identificadas pela sua cor. Os resultados } \\
\text { mostraram a presença de grande quantidade de } \\
\text { colônias de } C \text {. albicans, Candida tropicalis e Candida } \\
\text { krusei. Após a escovação com cerdas macias, o } \\
\text { tratamento incluiu o uso de } 2 \% \text { de gel de U. } \\
\text { tomentosa, três vezes ao dia por } 1 \text { semana. O gel } \\
\text { cobriu toda a superfície da prótese e foi então } \\
\text { colocado na boca. Foi recomendado ao paciente } \\
\text { remover a prótese para dormir. }\end{array}$ & $\begin{array}{l}\text { Após } 1 \text { semana de tratamento, foi observado um } \\
\text { declínio da hiperemia da mucosa palatina e } \\
\text { redução do grau de DS. A análise micológica } \\
\text { encontrou uma redução significativa de todas as } \\
\text { colônias viáveis. O gel de } U \text {. tomentosa foi um } \\
\text { tratamento adjuvante tópico eficaz; entretanto, a } \\
\text { influência dos métodos de higiene prescritos deve } \\
\text { ser avaliada em estudos futuros. }\end{array}$ & $\begin{array}{c}\text { Tay et al. } \\
\text { (2014) }\end{array}$ \\
\hline
\end{tabular}

Constatou-se um aumento de $203,1 \%$ no número de publicações ao comparar os dois períodos considerados, antes e após 2009, registrando-se o ano de 1988, o mais antigo, em um artigo (3,0\%), seguido de 1996 em um artigo (3,0\%) e 2002 em três artigos (10,0\%). Entre 1988 e 2008, período 'antes de 2009', constatou-se um maior número de publicações em 2006, com 11 (33,0\%), seguido de 2005 com cinco $(15,0 \%)$. Além do período, verificou-se o percentual de pesquisadores brasileiros atuando na elaboração dos estudos, onde constatou-se 41,2\% (40) dos 97 artigos de interesse, considerados para a pesquisa.

Estudo bibliográfico semelhante (MARMITT et al., 2015), ao analisar artigos sobre as plantas medicinais da RENISUS com potencial antibacteriano relatou um aumento de $167 \%$ na quantidade de estudos mais antigos, até 1994, para os 10 anos seguintes, até 2004, o que demonstra um aumento constante nas pesquisas sobre plantas medicinais desde a década passada. No mesmo estudo, afirmou-se que $42,1 \%$ dos artigos pertenciam a brasileiros, porcentagem essa muito similar com a da pesquisa atual. Um dos motivos aparentes para o progresso das pesquisas antes e após o ano de referência se deve à listagem RENISUS, criada no país, o que pôde ter instigado a população acadêmica no aprimoramento dos conhecimentos acerca das plantas medicinais em questão. 
Foram relatadas as partes extraídas das plantas, cujas foram empregadas com maior frequência na realização dos testes antimicrobianos. Quando utilizado mais de um tipo de fragmento da planta no estudo, este também foi listado e contabilizado. Para $A$. vera, em sete $(77,8 \%)$ dos estudos relacionados à planta, a parte utilizada foi o gel fresco da parte mucilaginosa da folha, ou também chamado de extrato aquoso da folha; para G. max, em 15 (62,5\%) estudos foram utilizadas as sementes, ou cascos delas, e cinco $(20,0 \%)$ aderiram ao uso da farinha proveniente de diversas partes da planta, podendo ser folhas, caules e/ou frutos, para a realização dos testes antimicrobianos.

Da espécie M. piperita, todos $(100,0 \%)$ os estudos relacionados a ela fizeram o uso do extrato ou óleo essencial para as análises, esses sendo feitos a partir de diversas partes da planta, como ocorre em 11 (55,0\%) dos estudos, ou também apenas folhas secas e trituradas, modo utilizado em nove $(45,0 \%)$ desses. Para as plantas do gênero Mikania spp., M. glomerata apresentou-se o uso de diversas partes da planta em cinco $(71,4 \%)$ estudos e M. laevigata em todos $(100 \%)$, podendo essas frações serem folhas e/ou caule. Em dois $(66,7 \%)$ dos artigos relacionados à $S$. alba, utilizaram-se as folhas para a realização das análises, já a planta $S$. terebinthifolia apresentou o uso delas em nove $(36,0 \%)$ dos seus estudos, seguido dos frutos como segundo maior uso $(28,0 \%)$, em sete, e o caule em seis $(24,0 \%)$, incluindo sua casca, para as análises. Por último, para U. tomentosa, em quatro $(44,4 \%)$ dos estudos foi utilizada a casca do caule da planta e em outros quatro (44,4\%), o gel com porção ativa da planta.

Após a obtenção do material provido das plantas, foi necessário adquirir o subproduto para realizar as análises. Destaca-se neste quesito o uso de extrato das plantas presente em 50,5\% (49) dos estudos, seguida da obtenção do óleo essencial ( $23,7 \%$ ou 23 estudos) e extração do gel das espécies (6,2\% ou seis estudos). Das outras obtenções, foram isolados genes da planta (esses que sintetizam proteínas antimicrobianas) 10 estudos (10,3\%) e analisada sua eficácia antimicrobiana, o que ocorreu somente em $G$. max, além de se obter a emulsão ( $1,0 \%$ ou um estudo), molécula da planta ( $1,0 \%$ ou um estudo) e o filme antimicrobiano ( $1,0 \%$ ou um estudo) unicamente nessa espécie.

Do método em que se obteve o suco da planta ( $2,0 \%$ ou dois estudos) e o dentifrício ( $1,0 \%$ ou um estudo), $A$. vera foi a única espécie testada. Já da obtenção da tintura ( $2,0 \%$ ou dois estudos), seu uso ocorreu nos testes com as plantas S. terebinthifolia e M. glomerata. Dos voláteis orgânicos (1,0\% ou um estudo), a planta S. alba foi a única testada por esse subproduto. Viu-se que a planta com o maior número de testes possíveis fora G. max, com seis métodos utilizados, seguida de $A$. vera, com quatro. Quando analisados a respeito dos tipos de estudo, in vitro ou in vivo, têm-se que em 93 (aproximadamente 95,9\%) dos artigos foram relatados experimentos feitos a partir do estudo in vitro, enquanto em apenas seis (aproximadamente $6,2 \%)$ deles foram realizados estudos in vitro e in vivo.

Analisando os artigos a respeito dos tipos de patógenos utilizados, que podem ser um ou mais microrganismos testados para cada estudo, têm-se que em 73 (aproximadamente 75,3\%) foram feitas análises antimicrobianas com bactérias, em 39 (40,2\%) foram utilizados fungos e, ainda, em três $(3,1 \%)$ testou-se o efeito das plantas contra outros patógenos, como vírus e/ou protozoários. 
Constatou-se uma considerável diferença no uso dos patógenos para algumas plantas, como por exemplo a planta $G$. max, que em $18(75,0 \%)$ artigos se utilizaram bactérias no teste, enquanto que em apenas $8(33,3 \%)$ deles foram empregados fungos; ainda, para $M$. piperita, em $16(80,0 \%)$ estudos foram utilizadas bactérias, enquanto que, em apenas seis $(30,0 \%)$ os fungos fizeram parte do estudo; no caso de Mikania sp. (M. laevigata e M. glomerata), em sete $(100,0 \%)$ dos estudos foram utilizadas apenas bactérias nos testes. Já para as outras plantas cujas foram encontradas comprovações em artigos, a diferença entre os patógenos não foi tão considerável quanto as citadas anteriormente.

Para S. terebinthifolius, em 19 (76,0\%) dos artigos foram utilizadas bactérias, em 14 (56,0\%) fungos e ainda, em dois $(8,0 \%)$ desses artigos foram utilizados outros patógenos, como vírus e protozoários; nos artigos a respeito de $A$. vera, em seis $(66,7 \%)$ foram utilizadas bactérias enquanto que em cinco $(55,6 \%)$ foram usados fungos. Para $U$. tomentosa, foram utilizadas bactérias em 5 (55,5\%) dos estudos e o mesmo número de artigos para fungos; já para S. alba, em dois $(66,7 \%)$ estudos foram utilizadas bactérias nos testes, em um $(33,3 \%)$ fungos e em um $(33,3 \%)$ outros patógenos.

Em relação às metodologias empregadas, somaram-se nove métodos para a avaliação da atividade antimicrobiana das plantas. Notou-se um grande uso da técnica disco-difusão, estando presente em aproximadamente $65 \%$ dos artigos de interesse. Nesses ensaios, o patógeno primeiramente é cultivado em Placas de Petri contendo ágar adequado ao seu crescimento e, após determinado tempo, o antibiótico é aderido no meio de cultura em diferentes concentrações, permitindo o acompanhamento da ação antimicrobiana direta e a dosagem específica. Posterior à atividade, são comparadas as zonas de inibição nas placas e definidas as Concentrações Inibitórias Mínimas (CIM) dos compostos testados. Este método é o mais comum ao se analisar a ação antimicrobiana das substâncias em teste, de fácil execução e apresenta os resultados qualitativamente (CAMPANA et al., 2011).

Com a metodologia anterior, a segunda mais utilizada, que junto à primeira somam $8,2 \%$ dos estudos e somente ela em $6,2 \%$, foi a técnica de microdiluição, que consiste em inocular os patógenos e testar vários tipos de potenciais antimicrobianos, o que facilita nas pesquisas com variadas plantas medicinais; os resultados também são lidos pelo valor CIM. Este método é considerado o mais adequado, já que seus resultados se expressam quantitativamente, porém tem custo elevado e demanda maior trabalho para fazêIo (CAMPANA et al., 2011).

Dos outros métodos também se destacou o uso tópico para fins de limpeza bucal, sendo elas a escovação com o dentifrício da planta medicinal em questão na dentição animal contaminada por patógenos, presente em três $(3,0 \%)$ estudos pertencentes às plantas $A$. vera e $U$. tomentosa, e através do enxágue bucal com subproduto de $M$. glomerata e $M$. laevigata em quatro $(4,1 \%)$ estudos, verificando a ação do produto ao longo das aplicações para se obter o potencial antimicrobiano.

Foram ainda empregadas diversas outras metodologias para os testes antimicrobianos de acordo com a planta em questão, citando o método por encapsulamento do subproduto em nanocápsulas, ou nanopartículas, em dois (2,0\%) estudos, um em A. vera e outro em S. alba; A aplicação do subproduto em frutos, segmentos de pele e em produtos industrializados também foi empregada, sendo a técnica presente 
em seis $(6,2 \%)$ estudos. O método de pirólise ocorreu em um (1,0\%) estudo de G. max; a macrodiluição (1,0\%) e microatmosfera $(1,0 \%)$ foram técnicas empregadas em dois estudos de $M$. piperita e por fragmentação ocorreu em um (1,0\%) estudo de Mikania spp.; outros tipos, somente um (1,0\%) estudo, em S. alba. Ainda no contexto das metodologias utilizadas, têm-se que em estudos de quatro plantas foram feitas análises a nível clínico, tanto em humanos, quanto em outros animais e também tecidos.

\section{CONCLUSÕES}

A partir desta pesquisa, foi constatado que S. terebinthifolia, G. max e M. piperita foram as plantas que se apresentaram eficazes em um maior número de artigos selecionados neste estudo. Sendo assim, pode-se ter uma maior confiabilidade em utilizá-las para fins medicinais, mais especificamente na ação antimicrobiana. A respeito da estrutura da planta mais utilizada para a comprovação do efeito, percebe-se que há uma diversidade de partes vegetais que podem ser estudadas, porém há o predomínio do uso das folhas, visto que é a porção botânica que mais interage diretamente com o ambiente, apresentando variadas especificidades.

Pode-se concluir também que para todas espécies o efeito medicinal é comprovado, visto que estas estão citadas nas listas oficiais de uso no Sistema Único de Saúde (SUS), RENISUS e RENAME, e os estudos mencionados auxiliam a confirmar a sua eficácia. As plantas $C$. scolymus, H. procumbens, M. ilicifolia e $R$. purshiana, apresentam efeito comprovado, visto que também constam nas listas anteriormente citadas, porém não foram encontrados estudos recentes e atualizados a respeito delas.

Conclui-se que são necessários mais estudos sobre o tema para reforçar e atualizar os dados sobre os efeitos medicinais das plantas, principalmente C. scolymus, H. procumbens, M. ilicifolia e R. purshiana, para as quais não foram encontrados artigos realizados posteriormente ao ano de 2009. Ainda, visto que o Brasil é um país com rica biodiversidade, os estudos se fazem necessários a fim de explorá-la para o incremento do conhecimento científico brasileiro a respeito de plantas que podem contribuir com a saúde e qualidade de vida da população.

\section{REFERÊNCIAS}

ALMEIDA, C. F. C. B. R.; CABRAL, D. L. V.; ALMEIDA, C. C. B. R.; AMORIM, E. L. C.; ARAÚJO, J. M.; ALBUQUERQUE, U. P.. Comparative study of the antimicrobial activity of native and exotic plants from the Caatinga and Atlantic Forest selected through an ethnobotanical survey. Pharmaceutical Biology, v.50, n.2, p.201-207, 2012. DOI:

\section{http://doi.org/10.3109/13880209.2011.596205}

ÂNGELO, T.; RIBEIRO, C. C.. Utilização de plantas medicinais e medicamentos fitoterápicos por idosos. C\&D: Revista Eletrônica da Fainor, v.7, n.1, p.18-31, 2014.

ANTUNES, R. M. P.; LIMA, E. O.; PEREIRA, M. S. V.; CAMARA, C. A.; ARRUDA, T. A.; CATÃO, R. M. R.; BABOSA, T. P.; NUNES, X. P.; DIAS, C. S.; SILVA, T. M. S.. Atividade antimicrobiana "in vitro" e determinação da concentração inibitória mínima (CIM) de fitoconstituintes e produtos sintéticos sobre bactérias e fungos leveduriformes. Revista Brasileira de
Farmacognosia, v.16, n.4, p.517-524, 2006. DOI: http://doi.org/10.1590/S0102-695X2006000400014

ANVISA. Agência Nacional de Vigilância Sanitária. Memento Fitoterápico: Farmacopeia Brasileira. Brasília: ANVISA, 2016.

BADKE, M. R.; BUDÓ, M. L. D.; SILVA, F. M.; RESSEL, L. B.. Plantas medicinais: o saber sustentado na prática do cotidiano popular. Escola Anna Nery, v.15, n.1, p.132-139, 2011. DOI: http://doi.org/10.1590/S141481452011000100019

BRASIL. Decreto n.5813 de 22 de junho de 2006. Aprova a Política Nacional de Plantas Medicinais e Fitoterápicos e dá outras providências. Brasília: DOU, 2006.

BRASIL. Ministério da Saúde Programa Nacional de Plantas Medicinais e Fitoterápicos. Brasília: MS, 2009. 
BRASIL. Relação Nacional de Medicamentos Essenciais: RENAME 2018. Brasília: MS, 2018.

CAMPANA, E. H.; CARVALHAES, C. D.; BARBOSA, P. P.; MACHADO, A. M. O.; PAULA, A. M.; GALES, A. C.. Avaliação das metodologias M.I.C.E. ${ }^{\circledR}$, Etest ${ }^{\circledR}$ e microdiluição em caldo para determinação da CIM em isolados clínicos. Jornal Brasileiro de Patologia e Medicina Laboratorial, v.47, n.2, p.157-164, 2011. DOI: http://doi.org/10.1590/S1676$\underline{24442011000200011}$

LESSA, F. C. R.; GRILLO, C. H. B.; PINTO, F. E.; LORENÇON, B. B.; MARTINS, J. D. L.; BERTOLUCCI, S. K. V.; PINTO, J. E. B. P.; ENDRINGER, D. C.. Efficacy of guaco mouthwashes (Mikania glomerata and Mikania laevigata) on the disinfection of toothbrushes. Revista Brasileira de Farmacognosia, v.22, n.6, p.1330-1337, 2012. DOI: http://doi.org/10.1590/S0102$\underline{695 \times 2012005000115}$

MACIEL, M. A. M.; PINTO, A. C.; VEIGA-JUNIOR, V. F.. Plantas medicinais: a necessidade de estudos multidisciplinares. Química Nova, v.25, n.3, p.429-438, 2002. DOI: http://doi.org/10.1590/\$0100-40422002000300016

MARMITT, D. J.; REMPEL, C.; GOETTERT, M. I.; SILVA, A. C.. Análise sistemática da produção científica de Zingiber Officinale roscoe após a criação da relação nacional de plantas medicinais de interesse ao sistema único de saúde. Arquivos de Ciência da Saúde, v.22, n.4, p.14-21, 2015. DOI: http://doi.org10.17696/2318-3691.22.4.2015.181
MARMITT, D. J.; REMPEL, C.; GOETTERT, M. I.; SILVA, A. C. Plantas medicinais da Relação Nacional de Plantas Medicinais de Interesse ao Sistema Único de Saúde com potencial antiparasitário. Scientia Amazonia, v.4, n.3, p.5462, 2015

MARMITT, D. J.; REMPEL, C.; GOETTERT, M. I.; SILVA, A. C. Plantas com potencial antibacteriano da Relação Nacional de Plantas Medicinais de Interesse do Sistema Único de Saúde: revisão sistemática. Revista de Saúde Pública de Santa Catarina, v.8, n.2, p.135-152, 2015.

PESSINI, L.; BARCHIFONTAINE, C. P.. Bioética e longevidade humana. São Paulo: Loyola, 2006.

ROCHA, F. A. G.; ARAÚJO, M. F. F.; COSTA, N. D. L.; SILVA, R. P.. O uso terapêutico da flora na história mundial. Holos, v.1, p.49-60, 2015. DOI:

http://doi.org/10.15628/holos.2015.2492

SILVA, L. E.; QUADROS, D. A.; MARIA NETO, A. J.. Estudo etnobotânico e etnofarmacológico de plantas medicinais utilizadas na região de Matinhos - PR. Ciência e Natura, v.37, n.2, p.266-276, 2015. DOI:

http://doi.org/10.5902/2179460X15473

VEIGA-JUNIOR, V. F.; PINTO, A. C.. Plantas medicinais: cura segura?. Química Nova, v.28, n.3, p.519-528, 2005. DOI: http://doi.org/10.1590/S0100-40422005000300026

A CBPC - Companhia Brasileira de Produção Científica (CNPJ: 11.221.422/0001-03) detém os direitos materiais desta publicação. Os direitos referem-se à publicação do trabalho em qualquer parte do mundo, incluindo os direitos às renovações, expansões e disseminações da contribuição, bem como outros direitos subsidiários. Todos os trabalhos publicados eletronicamente poderão posteriormente ser publicados em coletâneas impressas sob coordenação da Sustenere Publishing, da Companhia Brasileira de Produção Científica e seus parceiros autorizados. Os (as) autores (as) preservam os direitos autorais, mas não têm permissão para a publicação da contribuição em outro meio, impresso ou digital, em português ou em tradução. 